\title{
En nytolkning av Birka-amuletten
}

\author{
Sofia Pereswetoff-Morath \\ (Kiel University, Stockholm University)
}

\begin{abstract}
The aim of this paper is to provide a new reading and interpretation of the runic inscription on a silver capsule pendant from Birka which has been dated to the early Viking Age, 775-900 CE. It was found in a female grave and in the runological literature is conventionally known as the Birka amulet. The circumstances of the find are first discussed in order to establish the exact location of the pendant in the grave. This is followed by a discussion of the possible identity of the woman in the grave and the possible location of the amulet on her body. As regards the function of the pendant, it has been determined that it was repurposed from another object in order to serve as a scent box and it was at that time that the runic inscription was carved on the reverse side. Earlier readings and interpretations are then discussed, followed by an analysis of the reading order of the inscription. A new reading based on three separate examinations with stereo microscope is subsequently suggested and illustrated with photographs. To conclude, having established both reading order and reading, a new interpretation is suggested for the entire inscription.
\end{abstract}

Keywords: Birka/Björkö, early Viking Age, runes on non-monumental objects, younger futhark, reading order, magic formulas, amulets, pendants, capsules, scent boxes

$F^{\circ}$ öremålet för denna studie, som i runologisk litteratur oftast kallas Birka-amuletten, hittades 1878 på Björkö, norr om Borg, i kistgrav nr 552. Det skedde inom ramarna för de undersökningar som Hjalmar Stolpe ledde under perioden 1873 till 1895, under vilka 1100 gravar grävdes upp på Björkö. Inskriften på föremålets baksida upptäcktes dock först 1932 av Holger Arbman, då denne gick igenom fyndmaterialet från Stolpes undersökningar. Arthur Nordén skriver (1937, 160) att Arbman uppmärksammade inskriften 1934, men det motsägs av inskriftens publicering 1933

\footnotetext{
Pereswetoff-Morath, Sofia. "En nytolkning av Birka-amuletten." English: "The runes on the Birka amulet revisited."

Futhark: International fournal of Runic Studies 11 (2020, publ. 2021): 85-118. DOI: $10.33063 /$ diva- 438136
} 


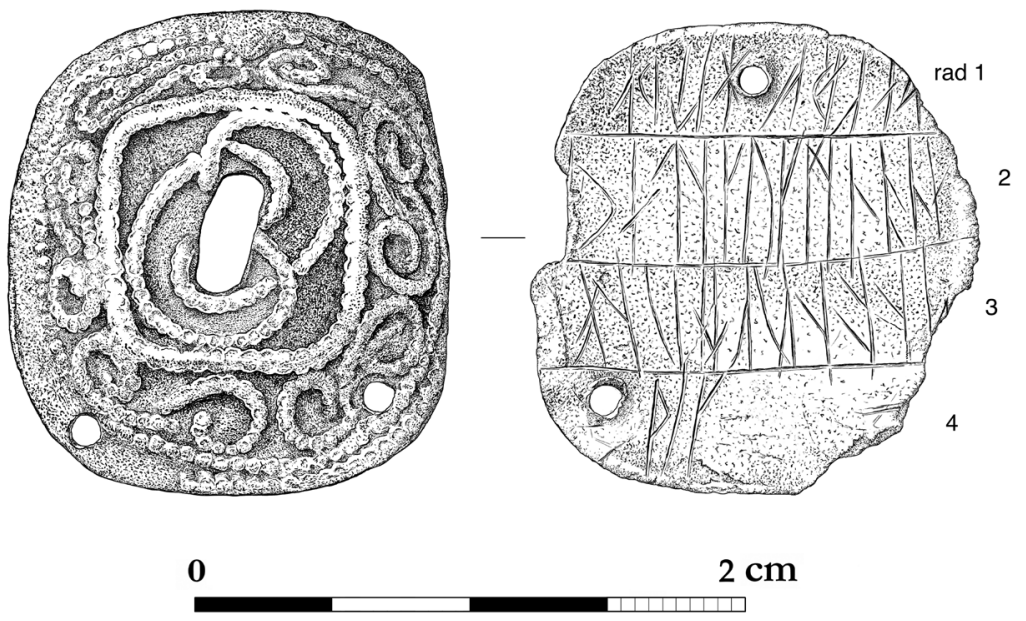

Fig. 1. Birka-amuletten. Teckning av Ksenia Dubrovina baserad på författarens undersökningar, fotografier och illustrationer.

i Stockholmstidningen (Nordén 1933) och med dateringen av dess fotografi i ATA till 1932. Arbman måste ha lagt märke till inskriften 1932 eller tidigare.

Föremålet är ett konvext kapselhänge av nästan kvadratisk form på $1,7 \times 1,6 \mathrm{~cm}$ (fig. 1). Det är tillverkat av förgyllt silver och har dekorerats med en filigrantråd. Dess funktion har utan tvekan varit att hålla något slags stoff, t.ex. örter eller doftämnen, men det består av delar som i sin tur kan haft andra funktioner. Således föreslår Władysław Duczko (1985, 66) att den dekorerade framsidan ursprungligen har ingått i en ornamental komposition på ett större objekt, men att den blivit avskuren och omvandlats till en doftkapsel med hjälp av den silverplatta som nu bilder föremålets baksida och bär runinskriften. Det är svårt att säga vad för slags större objekt det kan ha varit en del av, men Duczko menar att det kan ha varit fråga om en relikgömma på pärmarna av en kyrkobok. Duczko föreslår också att dess ursprung kan vara karolingiskt. Framsidan är dekorerad med pärlad tråd, som formats i c- och s-liknande figurer. På framsidan finns också en sekundär öppning i mitten, i vilken, om jag har förstått Duczko rätt, doftämnena skulle stoppas. Längs kanterna finns tre hål. Deras funktion var att förena den konvexa framsidan med baksidan och på så sätt skapa ett förvaringsrum inuti. I ett av hålen har det funnits en nit av brons och en ögla av silver som var fäst med niten. Nu finns inte längre några spår av niten eller öglan, men i ATA:s samlingar finns ett 


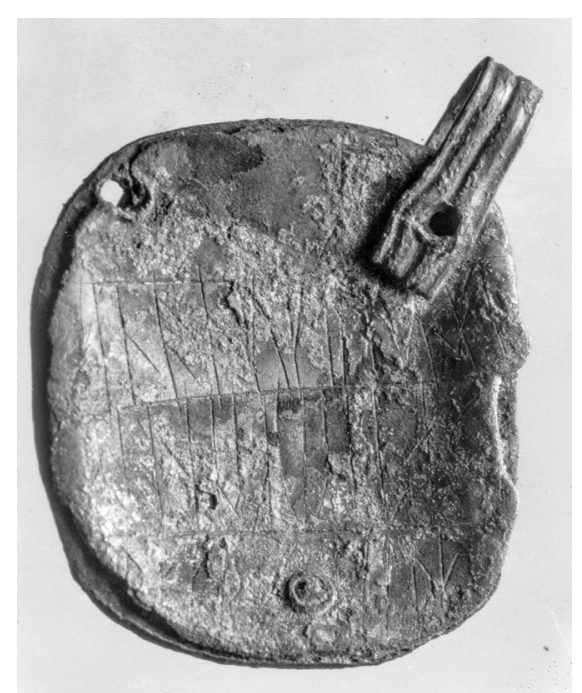

Fig. 2. Fotografi av Birka-amuletten från 1932 ur ATA:s arkiv (orientering upp och ner i förhållande till fig. 1). Foto: Harald Andersson (Public Domain).

fotografi av föremålet där både niten och öglan är intakt (fotografi 1371:20 taget av H. Andersson, se fig. 2). Samma fotografi publicerades i Stockholmstidningen 1933 av Arthur Nordén.

Runinskriften bör ha tillkommit i samband med att föremålet formades om, då - enligt vad jag kan se - hålen gjordes efter det att runorna ristades. Arthur Nordén $(1937,164)$ gör samma iakttagelse, men Hanna Åkerström $(2020,91)$ menar att förhållandet var det omvända; hon har dock inte undersökt själva föremålet. Jag måste kort också kommentera kapselns nuvarande skick: på Nordéns bild (1937, fig. 10) kan man se alla de tre hålen på baksidan. Idag är kanterna trasiga, och ett av hålen saknas helt. När detta skedde är oklart, men när jag såg hänget för första gången i december 2008 var kanterna redan i detta skick.

Jag kommer senare i artikeln att gå igenom runinskriften i detalj, men innan jag gör detta vill jag undersöka föremålets arkeologiska kontext. Två frågor intresserar mig särskilt: Vad kan man säga om personen i graven? Och: Vad kan man säga om föremålets plats i personens dräkt?

\section{Personen i grav 552}

Graven har daterats till Birkas äldsta period (775/800-900-talet) och könsbestämts med hjälp av de rika gravgodsen (Arbman 1943, 174 f.; en kortare 
beskrivning på svenska med några fotografier finns på: http://historiska. se/upptack-historien/foremal/silverhange-med-runinskrift/). Så vitt jag vet har ingen osteologisk analys eller DNA analys utförts för graven. Ingmar Jansson (pers. brev till författaren 14.05.2020) har meddelat att denna grav bör dateras ännu tidigare, eventuellt från perioden mellan 700-talets andra hälft och 800-talets andra hälft. På en så tidig datering visar enligt honom bl.a. de ovala spännbucklorna av berdalstyp (P16).

Utan tvekan tillhörde graven en förnäm kvinna (se fig. 3). Den innehöll två fina, ovala, förgyllda spännbucklor av brons som är dekorerade med karolingiska rovdjur samt ett likarmat spänne, som skulle förenas med de ovala spännbucklorna med hjälp av en virkad silvertråd. Ett nålhus av brons, som bara bevarats fragmentariskt, skulle hänga från den vänstra spännbucklan på en $18,5 \mathrm{~cm}$ lång silverkedja. Även fragment av en bygelsax av järn samt en järnkniv hittades i graven; dessa skulle hänga på bronskedjor från ett bälte. De ovala spännbucklorna skulle också förenas med hjälp av ett halsband bestående av 33 bärnstens- och glaspärlor och elva orientaliska silverhängen. Just på detta halsband skulle enligt min mening även vår silverkapsel hänga. Öglan på kapseln, som ännu fanns kvar 1932, hade samma utseende och storlek som öglorna på de orientaliska silverhängena. Att kapselhänget tillhör halsbandet framgår också av att det hittades liggande tillsammans med pärlorna och de orientaliska hängena under den högra spännbucklan (Arbman 1940a, 175). Liknande halsband med pärlor och silverhängen återfanns i många andra kvinnogravar på Birka; således innehöll grav nr 632 ett fint halsband bestående av pärlor, hängen och även ett par mynt som gjorts om till hängen. Halsbandet hittades på ett liknande ställe som i grav 552, nära den högra spännbucklan (Arbman 1940a, 212, se också planschen i Arbman 1940b, 119). Nordéns förslag $(1937,161)$ att det skulle "varit fråga om en fastnitning vid ett underlag", att Birka-amuletten skulle vara (s. 168) "nitad fast på ett bälte [eller] ett dolkfäste" finner jag omotiverat. Det förklarar inte öglans syfte och föremålets placering i graven.

De elva så kallade "orientaliska" hängena är mycket intressanta. Deras ursprung preciseras inte av Arbman. Sju av dem har en och samma bild: en kvinna som sitter på knäna med armarna öppna. Tre har en annan bild i form av ett oxhuvud. På ett hänge är bara ett växtliknande motiv avbildat. Jag har gått igenom hela Birkamaterialet för att se om det finns några liknande hängen i någon annan grav. Ingenstans kunde jag hitta samma hängen med den sittande kvinnan; jag fann dock hängen med precis samma typ av oxhuvud i grav nr 606. Att grav 606 innehåller samma slags hängen med oxhuvuden har inte uppmärksammats tidigare, 


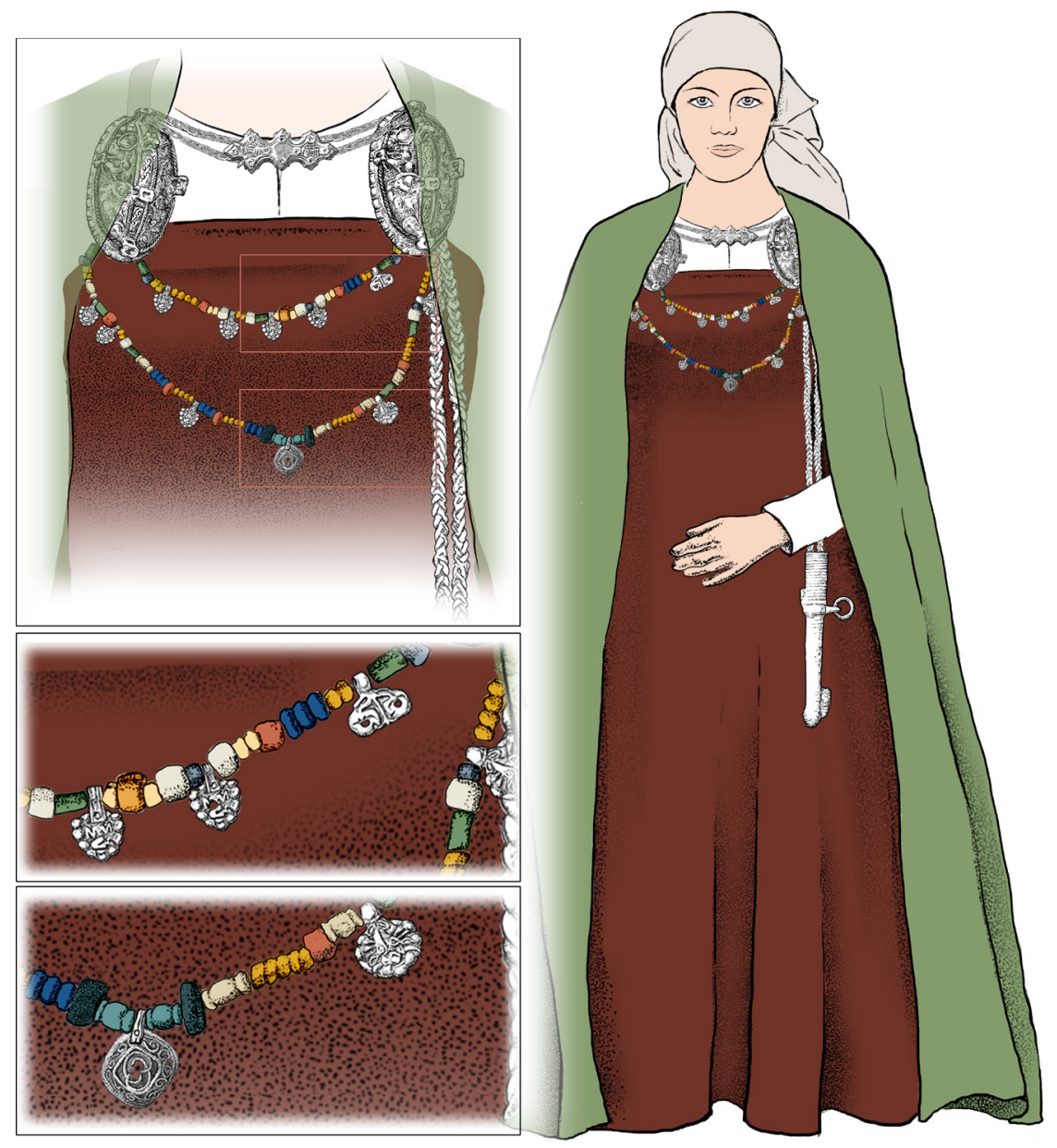

Fig. 3. Kvinnan i grav 552. Teckning av Ksenia Dubrovina baserad på författarens fotografier och sketcher.

eftersom de beskrivs som hängen "med orientalisk växtornamentik" (https://historiska.se/upptack-historien/object/785734/). Något som heller inte uppmärksammats tidigare är att samma grav sannolikt har en silverkapsel utan lock av kaptorga-typen. Det beskrivs förvisso som ett hänge (https://historiska.se/upptack-historien/object/852794/) men liknar mycket kaptorga-kapseln i grav 1062 (Arbman 1940b, plansch 92:17, se också Duczko 1980, 346). Kapseln i grav 606 verkligen beskrivs av Duczko $(1985,61)$ som en kapsel av kaptorga-typen; han menar (s. 63) att 
sådana kapslar "served as receptacles for some sweet-smelling, probably vegetable substance". Detta något märkliga sammanfall mellan typen av hängen i grav 606 och grav 552, liksom närvaron av silverkapslar med liknande funktion i de bägge gravarna, stärker sambandet mellan silverkapseln med runinskrift och de elva orientaliska hängena.

De 18 spikar som hittades i graven kan också berätta sin historia. Det mest frekventa antalet spikar för en gravkista på Birka ligger mellan 10 och 20 styck (Gräslund 1980, 17), varför antalet spikar i grav 552 ligger inom ramarna för vad som är typiskt. Deras placering avslöjar att kvinnan begravdes i en rektangulär träkista. Enligt Anne-Sofie Gräslund är denna kistform den mest populära på Birka (s. 17). Så långt kan man konstatera att kvinnan fick tidens populäraste kista. Mer sällsynt är att kistan hade ett lock. Många kistor från Birka saknar lock; lock är dock inte helt okända, och just kistan i grav 552 avbildas i Gräslunds avhandling (s. 16, fig. 11) som exempel på en typisk gravkista av mellanstorlek med lock. Det är också typiskt att hitta just en kvinna i en gravkista i Birka: de flesta kistgravar i Birka har identifierats såsom tillhörande kvinnor (s. 15). Kvinnans position på rygg i graven samt gravens orientering (västöst, Gräslund s. 29) är också typiska. Det är dock intressant att notera att kistgravar i sig, i synnerhet med spikade kistor, var en innovation. Gräslund (s. 43) skriver: "Nothing comparable is known from the Vendel Period or earlier in Central Sweden. Many nailed coffins can be dated to the Early Period at Birka, probably even to the beginning of this period, in other words the town's first decades." Denna innovation kommer förmodligen från kontinenten och kan ha samband med kristendomen; särskilt trapetsoidformade spikkistor på Birka har kopplats till den nya religionen av Gräslund (s. 20). Innovationer i begravningsskick märks också i hur de flesta gravar norr om Borg saknade varje form av markering på markytan såsom rösen, stensättningar eller högar.

Också gravgodsen i grav 552 kan sägas vara typiska för Birkagravarna; kvinnans dräkt och smycken är alltså inte unika på något sätt. Enligt Gräslund (s. 81) innehåller häften av alla identifierade kvinnogravar på Birka fina ovala broscher. Inte ens det faktum att kvinnan hade smycken som avbildar kvinnor är något unikt. Smyckena som avbildar kvinnor (bl.a. valkyrior) finns t.ex. i gravarna nr 507, 825 och 968. Att kvinnor får med sig sina vardagliga arbetsredskap i graven, såsom nålhus, bygelsax eller knivar, är också vanligt. Arbman skriver (1939, 107 f.): "För att vi skola få något så när fullständig uppfattning om en vikingatida husfru, måste även ett annat mycket karakteristiskt inslag i dräkten nämnas. Det är det lilla knippe med textilredskap, sax, kniv, pryl, pincett, nålhus o. dyl., som 
ibland i förening med en nyckel hängde ned i kedjor eller band från ett av de ovala spännena, oftast det högra. Det måste ha varit särdeles obekvämt med dessa föremål som hängde och slog." Det är dock helt möjligt att inte alla de föremål som kan påträffas i en kvinnas grav behöver vara sådana som hon bar på sig i sitt vardagliga liv. Judith Jesch $(1991,19)$ skriver: "Unlike the almost obligatory jewellery, there is greater variation in which of these objects, if any, were buried with them. The objects reflect the rank and status of the dead woman, or the tasks she had undertaken in this life and thus the tasks it was expected she would undertake in the next. ... It is thus more difficult to generalise about women's lives and work from grave goods than it is to generalise about their habits of dress from their jewellery." Att säga något konkret om en kvinnas sysslor utifrån hennes gravgods är alltså sällan möjligt utöver att det var fråga om vanliga kvinnosysslor.

Det enda unika med kvinnan och hennes gravär då den lilla silverkapseln med runor på baksidan. Att inskriften på Birka-amuletten har en språklig mening råder det ingen tvekan om. Det är därför av yttersta vikt att läsa inskriften på ett metodiskt sätt för att sedan kunna tolka den. Jag kommer därför att nedan diskutera inskriftens läsning och läsordning med stor noggrannhet.

\section{Tidigare forskning}

Det första och enda försöket att både läsa och tolka inskriften tillhör Arthur Nordén. Först publicerade han ett fotografi av Birka-amuletten i Stockholmstidningen den 26 februari 1933, men utan något försök att läsa eller tolka dess runor. Han ville nämligen inte stå i vägen för Ivar Lindquist, som Holger Arbman hade anförlitat uppgiften att publicera inskriften (Nordén 1937, 160). Fyra år senare, när Ivar Lindquist ännu inte hade lagt fram något, publicerade Nordén sin läsning och tolkning. Även Otto von Friesen gjorde ett försök att tolka inskriften, sannolikt samma år som Nordéns tolkning publicerades (Duczko 1985, 65), men hans tolkning baserades helt på Nordéns läsning. År 2007 gjorde Lisbeth Imer och Thorgunn Snædal sin läsning, men utan att försöka tolka inskriften (i Imer 2007). Den senaste undersökningen gällde inskriftens läsordning och gjordes av Hanna Åkerström (2020). För maximal tydlighet väljer jag att i min presentation av läsningar nedan beteckna inskriftens fyra rader i enlighet med Åkerströms radnumrering (fig. 1).

Nordén indelar inskriften i två delar: del 1 (raderna 3-4) och del 2 (raderna 2-1). För att underlätta för läsaren, ordindelar jag translittereringen: 


\section{Del 1: anon $\widehat{k u k m}$ ur at $\mid$ rik}

Del 2: pat ik ukm nona | sakâr at hit pa

$\begin{array}{lllll}15 & 20 & 25 & 30 & 35\end{array}$

Trots att Nordéns läsning inte håller på flera punkter, vill jag ändå kort kommentera hans tolkning. Nordén normaliserar sin tolkning till fornisländska (vidare: fisl.). Han vill (s. 166) inleda inskriften med runföljden anonk, som han tolkar som det fisl. verbet annask 'taga sig an någon eller något, ombesörja' i 1 pers. sg. pres., annomk 'jag tager mig an, uträttar'. Att vi ser här $\mathbf{n}$ istället för $\mathbf{m}$, förklarar han med följande resonemang om ristarens bristfälliga ljudanalys: "Det dubbla inflytandet från det långa $n$-ljudet i ordets mitt och från nasalklangen i det ovanpå detta $n$ följande, utljudande $q$ 'et har tillsammans med nasalljudet i mediumändelsen skapat ett n-komplex i det lilla korta ordet, som blivit ristarens förmåga av ljudanalys övermäktig. Antingen har han själv sagt annąnk eller också har han trott, att han uttalat det så.” Som vi ser är förklaringen långsökt.

Runföljden ukm föreslår Nordén att tolka som adjektivet ungr och som en begreppsruna $\$ maðr som tillsammans skulle bilda en sammansättning ungmaðr'yngling'. Runföljden uR tolkar han som prepositionen úr'ut av'. Vidare urskiljer han i runföljden atrik ett icke-belagt men helt möjligt substantiv fisl. at-rek n. 'strävan mot ett föresatt mål'. Normaliseringen och översättningen blir följande (s. 167):

Annąnk ungmenni úr atrek

'Jag driver ynglingen bort från hans föresats.'

Den andra delen inleder Nordén med pat som han tolkar som det demonstrativa pronomenet sá 'denna' i neutrum ackusativ. Vidare läser han ik som det personliga pronomenet ek 'jag' och ukm som ungmaðr 'yngling' på samma sätt som i del 1. Med runföljden nona uppstår svårigheter: Nordén vill ha ett verb i 1 pers. sg. pres., men hittar inga passande verb i fornnordiska. Detta är dock inget hinder för Nordén; han föreslår att det kan ha funnits ett verb nana med betydelsen 'uttala trolldomsord' och hänvisar till Setrekammens inskrift (N KJ40, 560-600), som innehåller orden na och nanA, samt till Lis Jacobsens uttalande om att na kan ha varit "til det magiske vokabular hørende 'virkeord'”. Nordén gör tyvärr inget försök att förklara hur han har rekonstruerat ordet, inte heller i en senare artikel $(1940,323)$ där han upprepar samma tolkning. I en fotnot 
i bägge arbetena (1937, 168, fn 1; 1940, 323, fn 4) finner vi hans fråga om inte detta ord kan ha bildats på samma sätt som det dialektala verbet nanna 'gnola, nynna barn till sömns' samt hans förslag att jämföra med verbet gala.

Vidare ser Nordén ytterligare fyra ord. Han ser substantivet sqkf. 'sak, orsak' i runföljden sakar, som här då står i gen. sg. och kan betyda 'för den skull'. I sådant fall borde ordets ändelse egentligen ha återgetts med $\mathbf{R}$-runan och inte med $\mathbf{r}$-runan. Nordén ser prepositionen at i runföljden at. Han ser det demonstrativa pronominet hinn 'det där' i n. ack. hitt i runföljden hit, som pekar på ordet atrek 'föresats' i del 1, om jag förstår honom rätt. Slutligen tolkar Nordén pa som 3 pers. sg. pret. av det fornisländska verbet piggja 'få, ta imot', pá.

Nordén normaliserar del 2 på följande sätt (s. 168):

pat ek ungmenni nana sakar at hitt pá

'Detta [besvärjelsen i den första delen] uttalar jag i magiskt syfte över den unge mannen, emedan han redan lyckats förverkliga en del av sin föresats (hitt)'.

För att få någon begriplig mening av detta, måste man upprepa Nordéns mentala akrobatik, vilket inte är helt enkelt. Om man sammanfattar kort, menar Nordén att den i besvärjelsen åsyftade situationen kan ha varit "en erotisk intrig" som utspelar sig antingen mellan två rivaler för en kvinna, eller mellan två kvinnor som kämpar för en man. Den del av föresatsen som ynglingen nått eller förverkligat är alltså enligt Nordén den kärlek som ynglingen fått, en kärlek som inskriftens beställare velat göra slut på.

Otto von Friesen gjorde sannolikt år 1937 ett försök att läsa och tolka inskriften. Tolkningen finns i handskriven form och har publicerats av Duczko $(1985,65)$ i översättning till engelska. (Duczko hänvisar till von Friesens "Anteckningar V:52" på Uppsala universitetsbibliotek, men bladet som behandlar Birka-amuletten ligger inte där, utan på Runverket vid Riksantikvarieämbetet utan signum.) Tolkningen fick inget egentligt genomslag men omnämns av Signe Horn Fuglesang i hennes artikel om vikingatida och medeltida amuletter $(1989,16)$ : "Pendant capsules of silver occur sporadically in mid- and late-Viking contexts.... They presumably contained fragrant herbs, and one from Birka grave 552 has a runic inscription indicating that it was used ag[a]inst vermin (Duczko, 1985)."

Också von Friesen indelar inskriften i två delar: del 1 (raderna 4-3) och del 2 (raderna 2-1). Om man jämför med Nordéns läsordning, ändrar han bara läsordning för raderna i del 1: 


\section{Del 1: rik | a non אûkm ur at}

$1 \quad 5 \quad 10$

Del 2: pat ik ukm nona | sakârat hit pa

$\begin{array}{lllll}15 & 20 & 25 & 30 & 35\end{array}$

Normaliseringen till fornisländska och tolkningen lyder på följande sätt:

Reka nen’k ugg-m(aðr) úr át = Ugg-m(aðr) nen'k reka úr át.

pat ik ugg-maðr nenna! Sakar rað hitt pá.

'I egenskap av "skräckman" nänns jag (vinnlägger jag) mig om att driva ohyran. Detta må jag såsom "skräckman" vinnlägga mig. För den skull erhöll jag denna makt (eller: utbad jag mig denna makt).'

Hans tolkningsförslag åtföljs inte av några kommentarer. Jag vill dock kommentera det kort, trots att tolkningen inte håller, på grund av att flera runor bör läsas annorlunda. Om jag har förstått rätt, menar von Friesen att inskriften inleds med en infinitiv av verbet reka'drive, jage, forfølgje, drive bort' (Norrøn ordbok). Det är besynnerligt att ordets sista ljud ristades i rad 3 , trots att det finns mycket plats kvar att rista i rad 4. Runföljden nonk tolkar han som 1 pers. sg. pres. ind. av verbet nenna 'nenne, ha lyst til, finne seg i, bry seg om' (Norrøn ordbok) med ett personligt pronomen ek som här används enklitiskt. Den enklitiska användningen av pronomenet $e k$ efter finita verb är inte något problem, men verbet förväntas ha formen nenni i 1 pers. sg. pres. ind. Runan $\mathbf{M}$ tolkar han som en begreppsruna maðr. Vilket ord som skulle betyda 'ohyra', úr eller át, har jag inte förstått. Ordet át n. kan betyda 'mat', ordet úr n. kan betyda 'yr, fint regn, namn på runebokstaven for u' (Norrøn ordbok). Även om úrkan tolkas som prep. ór'or, utav, frå, bort frå' (Norrøn ordbok), är det fortfarande oklart hur át ska förstås.

Den andra delen av tolkningen (raderna 2-1) har också verbet nenna i 1 pers. sg. pres. konj. som alltså egentligen borde böjas nenni. Också den innehåller $\mathbf{M}$ som begreppsrunan maðr samt det personliga pronomenet $e k$ 'jag'. Runföljden sakâr tolkas förmodligen som substantivet $s q k \mathrm{f}$. 'årsak, grunn' (Norrøn ordbok) i genitivform och här har vi samma problem som med Nordéns förslag, att ordets ändelse skulle ha återgetts med R-runan istället för $\mathbf{r}$-runan. Att vidare tolka rat som rað är problematiskt: t-runan används inte för att beteckna $p$ i tidig vikingatida runsvenska. Ordet rað kan dessutom knappast betyda 'makt'. Runföljden hit tolkas av allt att döma som dem. pron. hinn 'det där' i neutrum, hitt. Den sista runföljden pa tolkas som verbet piggja 'få, ta imot, ta til takke' (Norrøn ordbok) i 1 pers. sg. pret. ind., pá. 


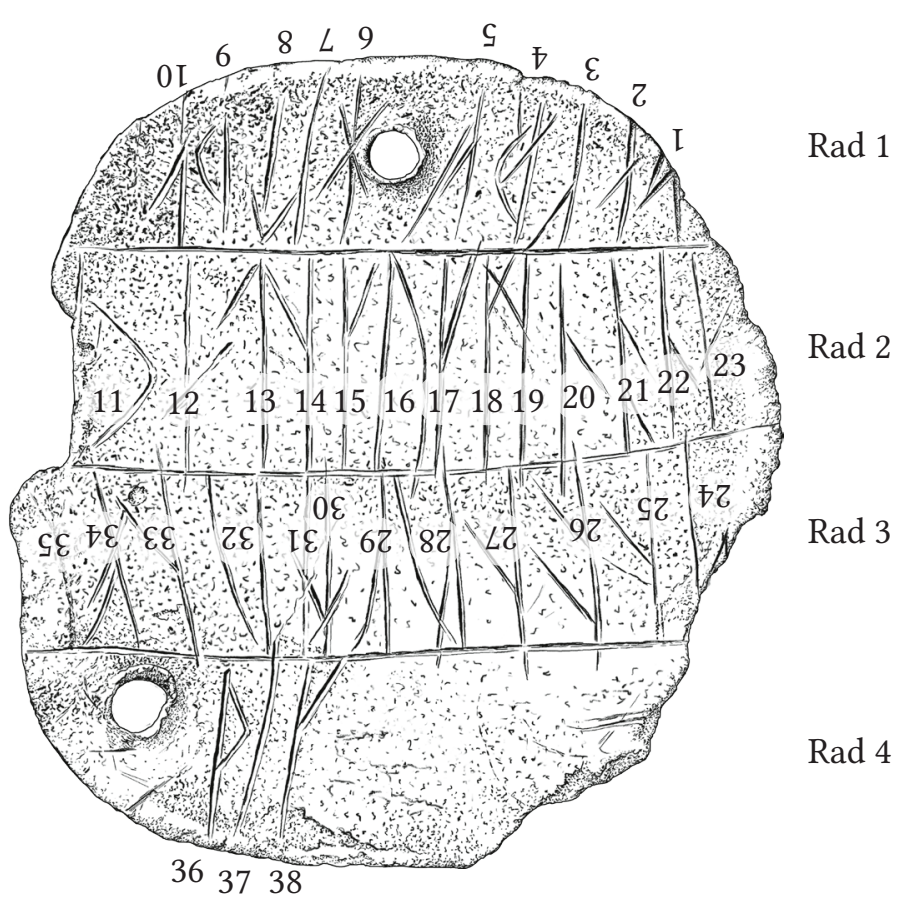

Fig. 4. Birka-amulettens inskrift med numrering. Teckning av Ksenia Dubrovina baserad på författarens fotografier och sketcher.

Förutom Nordéns läsning finns också den läsning som föreslagits av Lisbeth Imer och Thorgunn Snædal (i Imer 2007, 20). De läser raderna i ordning 2-3-1-4:

\section{patikukmnona | snonkukț̣infị | sakârf hitṛk | pik}

$\begin{array}{llllllll}1 & 5 & 10 & 15 & 20 & 25 & 30 & 35\end{array}$

Deras läsning skiljer sig kraftigt från Nordéns. De räknar bara med en äldre M-runa och läser vissa runor helt annorlunda. Rad 2 läser de på samma sätt som Nordén (r. 15-26 hos honom), men rad 3 inleds med runa $13 \mathbf{s}$ som Nordén läser som a (r. 1 hos Nordén). I stället för runa $\mathbf{M}$ (r. 7 hos Nordén) ser Imer och Snædal runorna ț̣ (r. 19-20). De urskiljer också två f-runor i inskriften, som Nordén inte ser. Imer och Snædal skriver att det blev klart för dem "at der ikke kan være tale om en magisk indskrift" men de argumenterar inte för varför inskriften inte kan vara magisk.

Hanna Åkerströms (2020) läsordning ämnar jag kommentera i ett separat avsnitt nedan. 

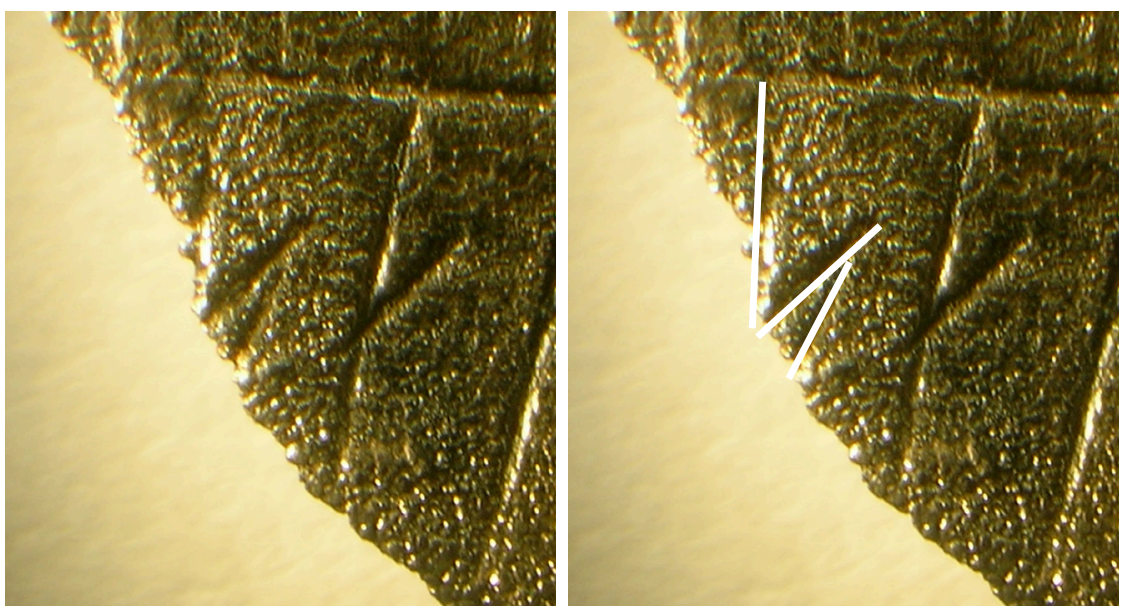

Fig. 5. Rad 1: runorna 1 och 2 (fotografiet till höger har vit färg i ristningslinjerna som är tillagd av författaren).

\section{Nyläsning}

Jag har undersökt hänget vid tre tillfällen: i december 2008, september 2009 och december 2010. Nedan går jag igenom inskriften runa för runa, från rad 1 till rad 4 (se fig. 4), men fokuserar särskilt på de runor som jag läser på ett sätt som skiljer sig från tidigare forskares. Translittereringen vill jag presentera oberoende av min nedan diskuterade läsordning, varför jag väljer att här följa den etablerade radordningen: 1-2-3-4. Terminologin följer Pereswetoff-Morath (2019b, 10 f.).

\section{sakârakhitp̣a | patikuitkinona | snonkukitunakị | pik}

Rad 1 börjar med en skadad s-runa (fig. 5). Man kan se runans övre stav, dess bistav som förenar stavarna samt den övre hälften av dess nedre stav. Trots skadan är läsningen säker. Runa 2 är $\mathbf{a}$ : dess bistav utgår från huvudstavens mitt och går upp till höger; den fortsätter även ett litet stycke på vänster sida och kan därför kallas för dubbelsidig.

Runa 3 är k, och dess form är den vanliga: bistaven utgår från huvudstavens mittre del, går upp till höger och når kantlinjen. Runa 4 är en bindruna $\widehat{\text { ar: }} \mathbf{a}$-runans bistav korsar tydligt huvudstaven, $\mathbf{r}$-runan består av en båge, som ansluter sig till huvudstaven i mitten av dess övre del, samt av en bistav som ansluter sig till bågens ände och går ner till höger. 


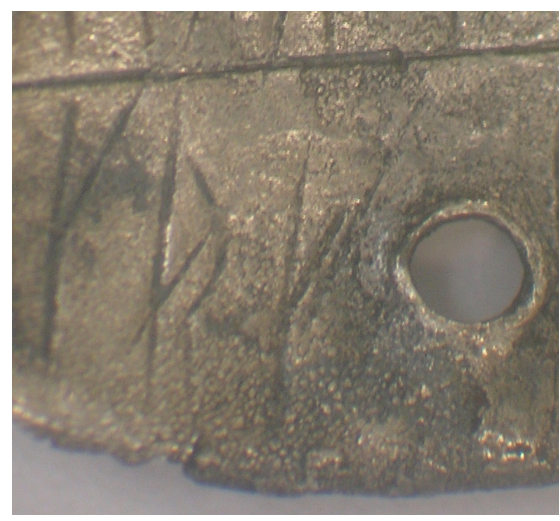

Fig. 6. Runorna 3-5

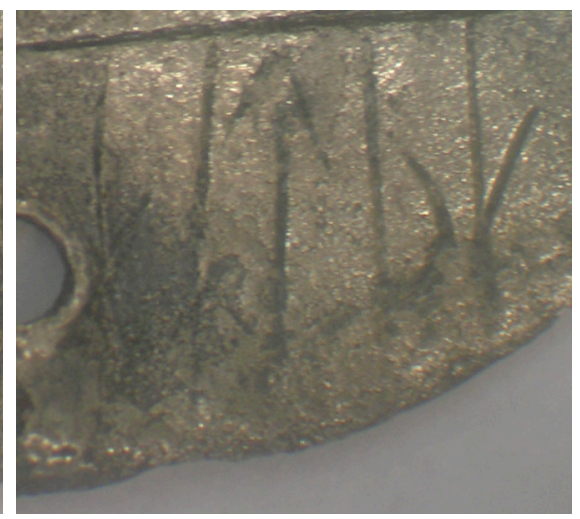

Fig. 7. Runorna 6-10

Runa 5 vill jag läsa som en bindruna $\widehat{\mathbf{a k}}$. Imer och Snædal läser den som ett $\mathbf{f}$ (r. 23 i deras läsning) medan Nordén läser den som ett $\mathbf{a}$ (r. 31 hos honom). Runan består av en huvudstav och två bistavar, den ena kort och den andra lång (fig. 6). Den korta bistaven är en $\mathbf{a}$-bistav; den motsvarar i sin form och position bistaven på runa 2 . Den långa bistaven går parallellt med den korta och fortsätter hela vägen till kantlinjen. Bistaven når dock inte kantlinjen och den ansluter inte heller till huvudstaven. Nordén läser denna bistav som ett $\mathbf{t}$ (r. 32 enligt hans läsning), trots att inga spår av den förmodade t-runans andra bistav eller huvudstav kan ses. Nordén (1937, 164) skriver: "Endast några ytterligt fina små spår ovanför nithålet förråda möjligen, att en linje här en gång funnits graverad", men jag ser inga sådana spår. Dessutom är bistaven för lång för att säkert uppfattas som t-runans. Imer och Snædal läser, som ovan sagts, denna bistav såsom ingående i runa 5 vilken de i sin tur läser som ett $\mathbf{f}$, men läsningen är osannolik, eftersom bistavarnas längd varierar så mycket. Det faktum att den korta bistaven korsar huvudstaven, medan den långa inte ens ansluter till den, gör också läsningen $\mathbf{f}$ mindre trolig. Det är intressant att notera att alla andra bindrunor som identifierats i denna inskrift innehåller en $\mathbf{k}$-runa.

Därefter kommer ett nithål. Dess uppbucklade kant på höger sida försvårar läsningen av runa 6, varför jag menar att hålen är sekundära i förhållande till inskriften. Runa 6 är ett $\mathbf{h}$; dess mittparti befinner sig alltså till höger om hålet, vars kant något döljer bistavarna (fig. 6 och 7). Runa 7 är ett i; i dess mittparti finns det spår av korrosion som påminner om ristade linjer, läsningen är dock säker. Runa 8 är ett $\mathbf{t}$ med två korta bistavar på ömse sidor om huvudstaven; huvudstavens nedre del har nötts bort. Runa 9 är antingen $\mathbf{r}$ eller $\mathbf{p}$. Den nedre delen av runan är alltför bortvittrad för 

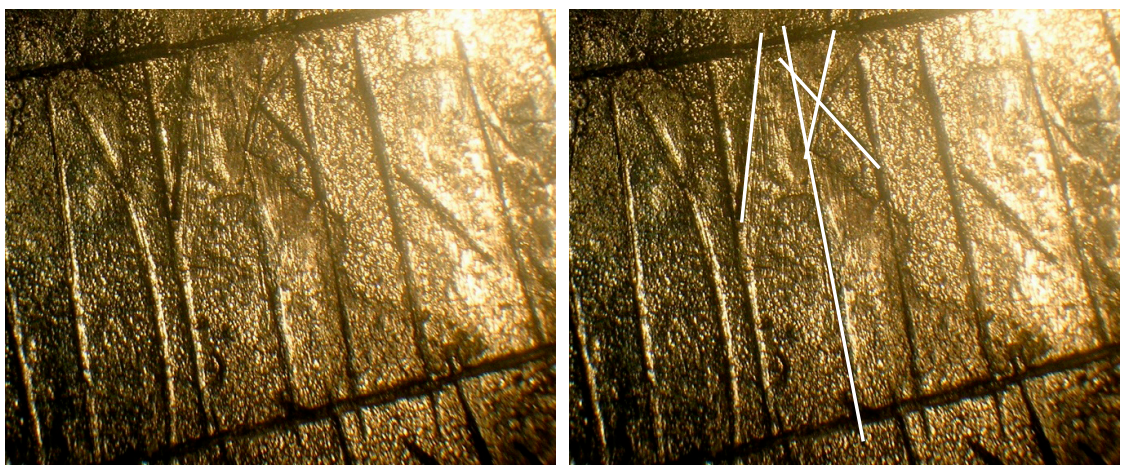

Fig. 8. Runorna 16-20 uitkin (fotografiet till höger har vit färg i ristningslinjerna som är tillagd av författaren).

att man skall kunna vara helt säker på att läsningen $\mathbf{r}$ kan uteslutas (fig. 7). För läsningen $\boldsymbol{p}$ talar bågens placering i mittdelen samt dess mjuka runda form, som kan jämföras med den något högre placeringen och smalare formen på $\mathbf{r}$-runan i samma rad (runa 4, se fig. 6). Runa 10 är utan tvekan ett $\mathbf{a}$. Imer och Snædal läser den som $\mathbf{k}$, men runans bistav är för kort för att vara en k-runas; dessutom korsar den huvudstaven något, alldeles som a-runornas bistavar gör i denna rad.

Rad 2 börjar också med en skadad runa: huvudstaven i runa $11 \mathbf{p}$ saknas delvis på grund av att en bit metall har flagrat bort i kanten och tagit med sig större delen av huvudstaven. Trots det är läsningen säker. Sannolikt fanns det inte någon runa framför runa 11, eftersom det saknas plats för detta. Runa 12 är ett $\mathbf{a}$ med en dubbelsidig bistav. Runa 13 är en t-runa med två bistavar, dess högra bistav är längre än den vänstra och når till huvudstaven på den följande runan.

Runorna 14-16 iku kan läsas utan problem. Runa 17 har tidigare lästs som ett k, medan runorna 18 och 19 lästs samman som ett äldre $\mathbf{M}$. Jag vill utforska möjligheterna för en annan läsning här, eftersom den tidigare resulterar i den svårtolkbara konsonantkombinationen kmn, vilket i sin tur har den olyckliga följden att $\mathbf{~} \mathbf{M}$ måste tolkas som en begreppsruna. I fig. 8 markerar jag med vit färg vilka linjer som är ristade. Om vi försöker läsa dem annorlunda, blir den mest sannolika lösningen iťk. Runa 17 vill jag läsa som i. Saken är den att dess förmodade k-bistav snarare hör till nästa runa, som då blir en bindruna $\widehat{\mathbf{t k}}$ med samma slags överlånga bistav på vänster sida som i runa 13. Denna bistav rör inte vid huvudstavens topp, utan missar den precis ovanför den övre radlinjen. Att bindrunan bör läsas $\widehat{\mathbf{t k}}$ och inte $\widehat{\mathbf{k t}}$, kan ses tack vare att $\mathbf{k}$-runans bistav är tydligt 

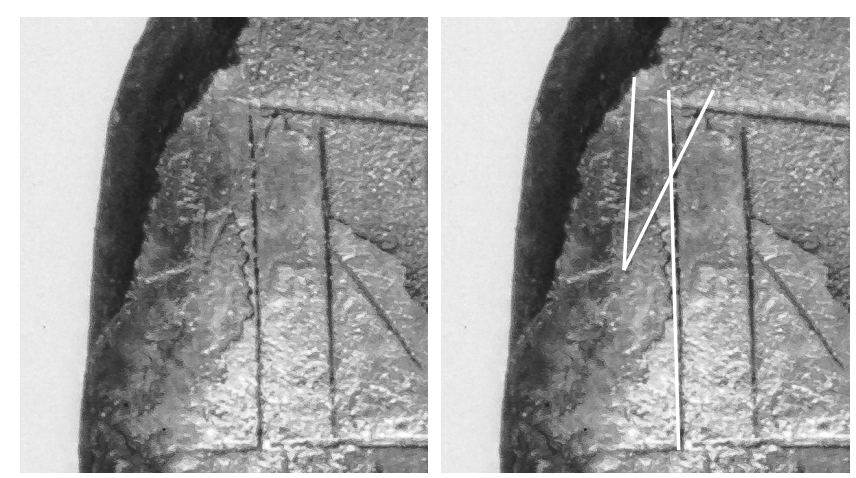

Fig. 9. Runa 24. ATA-fotografiet från 1939 efter rengöring (fotografiet till höger har vit färg i ristningslinjerna som är tillagd av författaren). Foto: Harald Andersson (Public Domain).
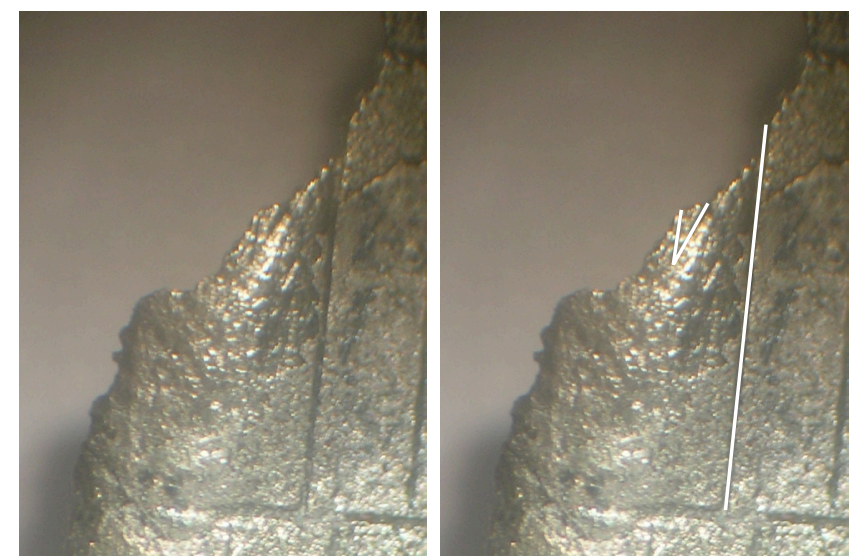

Fig. 10. Runa 24. Nuvarande skick (fotografiet till höger har vit färg i ristningslinjerna som är tillagd av författaren).

ristad ovanpå t-runans högra bistav. Läsningen av runan försvåras av en spricka i metallen som utgår från nästa runas topp och går ner till vänster för att delvis sammanfalla med k-runans bistav. Den försvåras också av en stark nötning på detta ställe.

Runa 19 är i: som jag redan framhållit är den linje som utgår från huvudstaven topp och går ner till vänster inte ristad, utan en spricka i metallen. Linjen som utgår från dess mittdel och går upp till vänster tillhör den föregående bindrunan och utgör t-runans högra bistav. Runa 20 är ett n med en bistav som utgår från huvudstavens mittre del och går ner till höger. Runa 21 är ett $\mathbf{0}$ med två bistavar på höger sida om huvudstaven; den nedre bistaven utgår från gränsen mellan huvudstavens mittre och nedre del, går ner till höger och når kantlinjen; den övre bistaven utgår 
från gränsen mellan huvudstavens övre och mittre del och går parallellt med den nedre bistaven. Runa 22 är ett $\mathbf{n}$ med en ensidig bistav. Runa 23 är ett $\mathbf{a}$ med en dubbelsidig bistav.

Rad 3 börjar med runa 24, vars övre del är borta på grund av att en bit metall i kanten flagrat bort. Denna runa lästes av Nordén som a (runa 1 i hans läsning). Man kan se en huvudstav som saknar överdel samt en bistav som utgår från skriftytans mittre del och går upp till höger, där den träffade den övre delen av huvudstaven, som nu är borta. Om vi undersöker det gamla ATA-fotografiet (fig. 2 och fig. 9), där hängets kant fortfarande är intakt, kan vi se att bistaven korsar huvudstaven och går hela vägen upp till radlinjen samt att det finns ytterligare en ristad linje som går rakt upp från bistavens vänstra spets hela vägen till radlinjen. Linjens nedre del syns fortfarande (fig. 10). Runa kan alltså läsas som s, vilket också Imer och Snædal gör. En liknande form med en lång huvudstav har t.ex. en s-runa på Solbergablecket 1 (Pereswetoff-Morath 2019a, 295; 2019b, 175).

Runa 25 är ett $\mathbf{n}$ med bistaven på höger sida om huvudstaven. Runa 26 är ett $\mathbf{0}$. Det är intressant att notera att dess övre bistav utgår nästan från toppen och inte som i runa 21 från den del av huvudstaven som ligger på gränsen mellan dess övre och mittre del. Runa 27 är ett $\mathbf{n}$.

Runa 28 har av alla lästs som en bindruna ku. Det är intressant att notera att $\mathbf{u}$-runans bistav är ristad ovanpå k-runans bistav, varför läsningen $\widehat{\mathbf{k u}}$ bör föredras framför $\widehat{\mathbf{u k}}$. Om vi för övrigt läser den som $\widehat{\mathbf{u k}}$, blir det svårt att förklara varför den nästföljande runan också skulle vara ett $\mathbf{k}$. Mindy MacLeod $(2002,152)$ bedömer att denna bindruna ristats av misstag. Hon förklarar dock inte vilket misstag som rättas, är det $\mathbf{k}$ eller $\mathbf{u}$ ? Tack vare noggrann undersökning av runorna genom mikroskop kan vi vara säkra på att det inte kan handla om ett $\mathbf{u}$, eftersom dess bistav är tydligt ristad ovanpå k-runans bistav (fig. 11). Inte heller kan det handla om att ett $\mathbf{k}$ har rättats, eftersom ju nästa runa är en k-runa. Jag håller alltså inte med MacLeod om att denna bindruna är ett resultat av en rättning. Möjligen kan MacLeods uppfattning om denna runa grunda sig i hennes antagande om att runinskrifter med kortkvistrunor sällan har avsiktligt ristade bindrunor. Denna inskrift räknar hon till dem som ristats med kortkvistrunor, trots att inskriften bara har en säker kortkvistrunform, nämligen $\mathbf{n}$.

Runa 29 är k. Runorna 30 och 31 läser Nordén som en äldre M-runa (r. 7 $i$ hans läsning). Imer och Snædal läser runa 30 som ett osäkert $\mathbf{t}$, och runa 31 som ett osäkert i. Jag vill läsa runa $30 \mathrm{som} \mathbf{i}$ och runa $31 \mathrm{som} \mathbf{t}$. Det finns en märklig sak här som är mycket viktig att notera. Om vi tittar noga på runa 31, kan vi märka att dess huvudstav ristades före den bistav som Imer och Snædal läser som t-runans högra bistav (fig. 12). Detta kan före- 


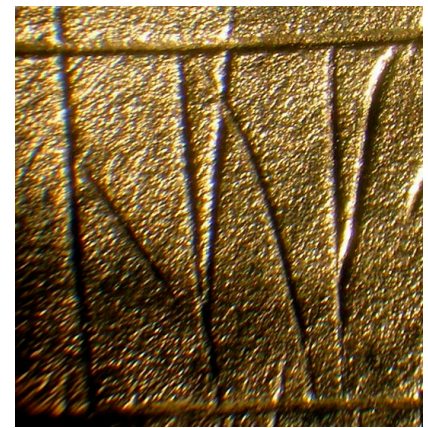

Fig. 11. Runorna 27-29

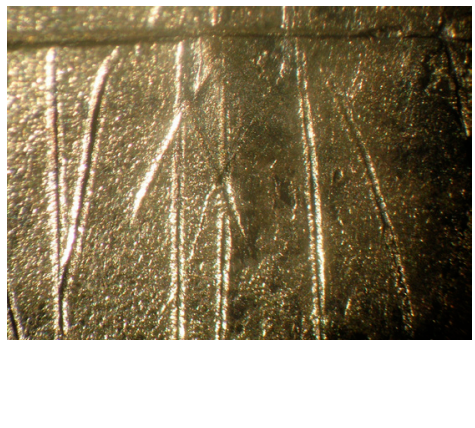

Fig. 12. Runorna 29-32

falla som en bagatell, men är det inte. Iakttagelsen möjliggör min läsning, nämligen att runa 30 är ett $\mathbf{i}$, medan runa 31 är ett $\mathbf{t}$. Man får inte glömma att runorna här är bara $3 \mathrm{~mm}$ höga, samt att avståndet mellan runorna 30 och 31 här är mycket litet: mindre än $2 \mathrm{~mm}$. Det är därför lätt för handen, även en så säker hand som ristarens, att missa t-runans huvudstav något och hamna längre åt vänster. Hade denna bistav hört till runa 30 skulle den ha behövt vara ristad före huvudstaven på runa 31. Åtminstone ristas alla andra runor i inskriften från vänster till höger.

Runa 32 är $\mathbf{u}$. Runa 33 har lästs som $\mathbf{R}$ av Nordén och som $\mathbf{n}$ av Imer och Snædal. Jag väljer de senares läsning; runan har bara en bistav på höger sida om huvudstaven som går ner till höger, och det finns inga spår av någon bistav på vänster sida om huvudstaven.

Runa 34 vill jag läsa som en bindruna $\widehat{\mathbf{a k}}$. Imer och Snædal läser den som ett $\mathbf{f}$, men runans bistavar motsäger en sådan läsning. Den nedre bistaven korsar huvudstaven i mitten och går både ner till vänster på vänster sida om huvudstaven och upp till höger på dess högra sida. Det är alltså en typisk dubbelsidig a-runabistav i denna inskrift. Den övre bistaven går parallellt med den nedre men är längre och når den övre radlinjen. Den ansluter dock varken till a-runans huvudstav eller till nästa runas huvudstav utan ligger närmare a-runans huvudstav. Det är denna bistav som Nordén läser samman med den efterföljande runan och får en kortkvistruna $\mathbf{t}$. Jag menar dock att läsningen $\widehat{\mathbf{a k}}$ är sannolikare än f eller $\mathbf{t}$ ( $\mathbf{t}$-runan har annars dubbelsidiga bistavar i denna inskrift). Nästan samma form har för övrigt runa 5 men med den skillnaden att $\mathbf{k}$-runans bistav där ligger under a-runans. Det faktum att en och samma bindruna har utformats något annorlunda i en och samma inskrift kan väcka frågor, men det är värt att påminna om runornas storlek här. Runa 34 är bara 3 

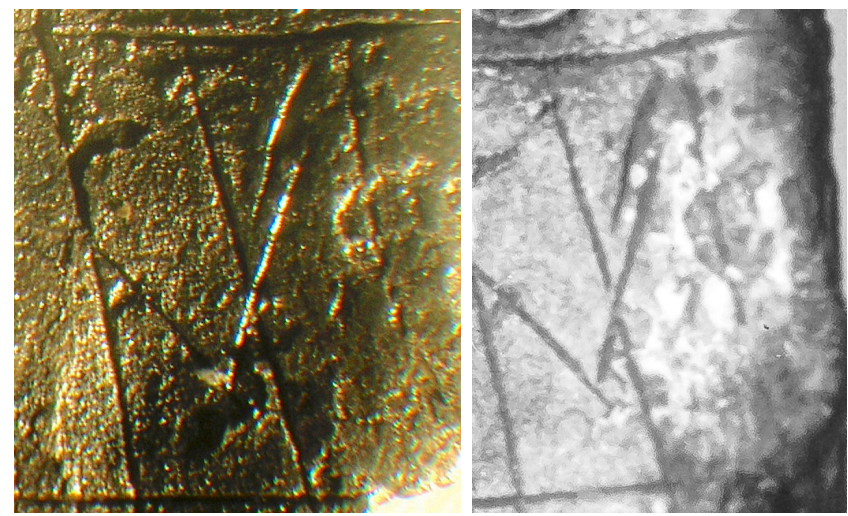

Fig. 13. Runorna 33-35 i nuvarande skick

Fig. 14. Runorna 33-35 på ATA-fotografiet från 1937. Foto: Harald Andersson (Public Domain).

mm högt och avståndet till nästa runa är 1,5 mm. Runans a-bistav kan ha hamnat lite lägre på huvudstaven än planerat, varvid det bara återstod att placera $\mathbf{k}$-runans bistav ovanpå $\mathbf{a}$-bistaven istället för under den.

Därefter ser Imer och Snædal en i-runa. Även Nordén ser en huvudstav som han alltså tillsammans med den föregående runans övre bistav läser som ett t. Jag ser en linje som är ristad, men som har avbrott på ett par ställen: den börjar vid övre radlinjen, går rakt ner men når inte till den nedre radlinjen, utan stannar i mitten av skriftytans nedre del (fig. 13). Alla de andra runorna i denna rad når kantlinjen med sina huvudstavar. Om vi emellertid går tillbaka till det gamla ATA-fotografiet (fig. 14), ser vi att linjen där är längre och definitivt ristad utan avbrott. Runan kan alltså utan problem läsas som $\mathbf{i}$.

Rad 4 består av tre runor. Runa 36 har lästs som $\mathbf{r}$ av Nordén och som $\mathbf{p}$ av Imer och Snædal. Om man noga undersöker runans nedre del, ser man ett svagt streck som knappast kan vara ristat (fig. 15, svart pil). Men även om det skulle vara ristat, skulle detta knappast ha kunnat göras avsiktligt. Runan $\mathbf{r}$ (r. 4) har en annan form i denna i inskrift. Det kan här således inte vara frågan om en $\mathbf{r}$-runa. Strecket är också mycket kort (fig. 16), varför det heller inte blir möjligt att läsa runan som en långkvistruna $\mathbf{b}$. Jag vill därför läsa runan som $\mathbf{p}$ på samma sätt som Imer och Snædal. Bågens höga placering på huvudstaven är inget problem för denna läsning (jfr Pereswetoff-Morath 2019b, 200-202). Runa 37 är i, och runa 38 är k.

Sammanfattningsvis kan sägas att runorna på Birka-amuletten för det mesta är av långkvisttyp. Det finns bara en runa som genomgående har kortkvistform och det är $\mathbf{n}$. Ibland har dock $\mathbf{a}$-runan en ensidig bistav 

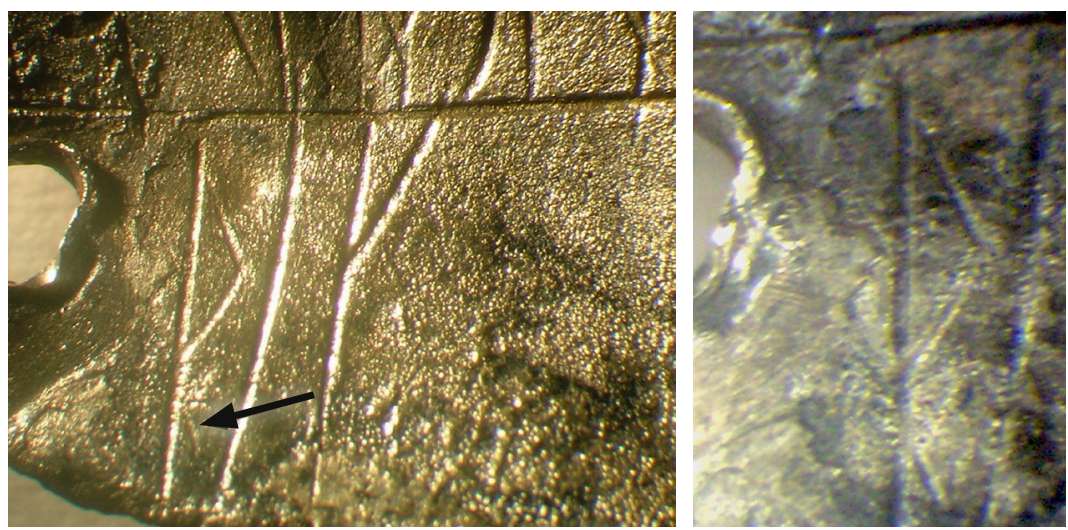

Fig. 15. Runorna 36-38 (med svart pil som pekar på strecket i runa 36 tillagd av författaren) Fig. 16. Runorna 36-37

som går upp till höger om huvudstaven, men oftast fortsätter bistaven också ner på vänster sida om huvudstaven. Formen på o-runan varierar något i denna inskrift (dess övre bistav utgår en gång nästan från toppen och en gång är den placerad $i$ huvudstavens mitt), men båda varianterna förekommer ofta i inskrifter ristade med långkvistrunraden. Magnus Källström $(2013,108)$ skriver att "o-runan med ensidiga bistavar är en naturlig del av långkvistrunesystemet fram till slutet av 900-talet”. Birka-amuletten kan därför tillsammans med en bennål hittad på Birka 1924 i Svarta jorden och daterad till 800-talet (U ANF1937;172, jfr Källström 2013, 110 f.) räknas till Birkas äldsta fynd ristade med långkvistrunor.

Inskriften har enligt min läsning inga äldre runor; den ena förmodade M-runan läser jag som en bindruna $\widehat{\mathbf{t k}}$, den andra som runorna it. De två f-runor som Imer och Snædal ser i inskriften läser jag som bindrunorna $\widehat{\mathbf{a k}}$. Tre nya bindrunor har således identifierats i inskriften.

\section{Läsordningen på Birka-amuletten och Åkerströms analysmodell}

Inskriften består av fyra rader, varav tre är fulla med runor, medan den fjärde består av endast tre runor (jfr fig. 1). Om raderna var tänkta att läsas vertikalt eller horisontellt, kan inte avgöras, och det kan heller knappast ha varit avgörande för läsordningen, eftersom det lilla hänget kan vridas och vändas åt vilket håll som helst. Storleken på runorna varierar: rad 2 har större runor än de övriga i inskriften, rad 3 har ungefär lika stora; 
Tabell 1. Birka-amulettens runor: antal, storlek och avstånd mellan runorna

\begin{tabular}{llll}
\hline Rad & Antal runor & $\begin{array}{l}\text { Höjd på de första tre } \\
\text { runorna i raden }(\mathrm{mm})\end{array}$ & $\begin{array}{l}\text { Avstånd mellan huvud- } \\
\text { stavar av de första tre } \\
\text { runorna i raden }(\mathrm{mm})\end{array}$ \\
\hline $\operatorname{rad} 1$ & 10 & $2-3$ & $1-2$ \\
$\operatorname{rad} 2$ & 13 & 4 & $2-3$ \\
$\operatorname{rad} 3$ & 12 & $3-4$ & $2-3$ \\
$\operatorname{rad} 4$ & 3 & $2-3$ & $1-2$ \\
\hline
\end{tabular}

därefter följer rad 1 och 4 som har storleksmässigt mindre runor. Runtätheten varierar också. I rad 2 står runor glesare än i den övriga inskriften. Glest står de också i början av rad 3. I rad 1 står de tätare än i den övriga inskriften. Samma gäller rad 4. Trots att rad 2 har större, glest placerade runor, är denna rad den längsta, om man räknar runorna till antalet. Rad 2 har 13 runor, rad 3 har 12, rad 1 har tio och rad 4 har tre. Rad 2 sticker därför ut visuellt, och rad 3 ligger visuellt närmast rad 2.

Jag börjar därför läsa inskriften från rad 2 och fortsätter med rad 3. Nu måste man välja vilken av de två resterande raderna längs kanten som kommer härnäst. Jag väljer att först läsa rad 1; den är helt täckt med runor, vilket kan förstås som ett tecken på att denna rad inte är den avslutande; den kan dessutom läsas utan att man behöver vända på hänget igen. Det faktum att man inte behöver vrida på hänget kan kompensera för ett hopp över rad 2 i kompositionen. Till sist läser jag rad 4 som endast har tre runor men i gengäld mycket plats för att fortsätta rista, vilket kan ses som en indikation på att denna rad skall läsas sist.

Min läsordning baseras således inte på inskriftens innehåll och inte ens på läsningen, utan på de visuella iakttagelser som jag sammanfattar i tabell 1. Det är för övrigt samma läsordning som föreslagits av Imer och Snædal (2-3-1-4), som signifikant nog inte heller förutsätter någon tolkning (Imer 2007, 20).

Läsordningen för hängets inskrift diskuteras i detalj av Hanna Åkerström i hennes artikel "Läsordning i tidigvikingatida runinskrifter" (2020, 91-94). Birka-amuletten, som hon kallar för Björköhänget, ingår som en av tre inskrifter på vilka hon prövar sin modell om läsordningen i tidigvikingatida runinskrifter.

Åkerström föreslår två möjliga läsordningar för inskriften: den ena är 1-2-3-4, den andra är 2-1-3-4. Enligt hennes analysmodell har den 
första läsordningen "ett starkare markerat erbjudande" (s. 94). Imers och Snædals läsordning 2-3-1-4 kommenterar hon kort som osannolik, eftersom den förutsätter att läsriktningen ändras två gånger. Jag kommer att diskutera denna kritik inom kort. Den läsordning som enligt Åkerström har "starkare markerat erbjudande", nämligen 1-2-3-4, menar jag vara mindre sannolik än den som enligt henne har ett något svagare markerat erbjudande, dvs. 2-1-3-4. Det förefaller ännu mer rimligt att, som Imer och Snædal, läsa rad 3 direkt efter rad 2, eftersom rad 2 och 3 visuellt liknar varandra betydligt mer än rad 2 och 1 .

Åkerströms motargument (att Imers och Snædals läsordning byter riktning två gånger och därför inte kan accepteras) kan jag inte riktigt förstå, eftersom inskriftens rader löper bustrofedon och på så sätt kan byta riktning varje gång en ny rad börjar. Åkerströms argumentation lyder på följande sätt: (s. 92)

Utifrån den uppsättning resurser jag urskilt kan placering av rad och radordning (d.v.s. varianten med lässtart i en mittrad och där läsordningen mellan raderna växlar riktning) sägas erbjuda Imers ordning. Dock växlar riktningen i Imers förslag vid två tillfällen, något som inte finns belagt i grupp 1 och är osannolikt mot bakgrund av Moltkes genomgång (i DR, Text, sp. 822 f., se ovan). Möjligen har Imer också följt resursen runstorlek då hon valt lässtart. Eftersom hon lämnar inskriften otolkad har dock knappast en språklig tolkning styrt.

Placering av rad, radordning, runstorlek och många andra benämningar (se tablå 1 på s. 80 i Åkerström 2020) är namn på de semiotiska resurser som Åkerström har urskilt i sitt arbete med tidigvikingatida runinskrifter. Åkerströms analys av de semiotiska resurserna grundar sig i sociosemiotisk teori och en multimodal syn på texter, som går ut på att allt runtomkring texten - layout och utformning av texten, ornamentik, bilder, rubriker och så vidare - har mening. Grupp 1 i Åkerströms analys är en grupp av tidigvikingatida inskrifter som har säker lässtart och läsordning, etablerade på språkliga grunder. Dessa inskrifter fördelar hon mellan ett antal tablåer: tablå 2 innehåller flerradiga inskrifter vilkas läsordning "kan bestämmas i sin helhet på språklig grund" (s. 108); tablå 3 innehåller inskrifter vilkas läsordning "inte kan bestämmas i sin helhet på språklig grund" (s. 110) men har segment som medger säker läsordning mellan raderna. Dessa segment ingår därigenom också i grupp 1.

Åkerström hänvisar till sin egen och Moltkes analys som stöd för sin kritik. I Moltkes genomgång i Danmarks runeindskrifter (Text, sp. 822 f.) finner jag emellertid inget som motsäger att man skulle kunna byta läsriktning två gånger i en inskrift. Åkerström säger dock att det i hennes grupp 
1, dvs. bland inskrifter med säker läsordning, inte finns några exempel på detta. Man kan då fråga sig hur många inskrifter det finns i Åkerströms grupp 1 som i ett och samma inskriftsparti har fyra rader (såsom Birkaamuletten) med en läsordning som säkert kan bestämmas. (Tyvärr anges varken läsriktning eller semiotiska resurser för inskrifterna i tablåerna 2 och 3, vilket försvårar arbetet för den som vill verifiera Åkerströms resultat.) Svaret är enligt hennes tablå 2 "inga" (s. 108 f.). Antalet inskrifter med tre rader i ett och samma inskriftsparti i grupp 1 är enligt samma tablå fyra. Av dessa fyra inskrifter har två rak läsordning (DR 40 och DR 41), medan de två andra har inskrifter som byter riktning två gånger (DR 29 och DR 202).

Man kan då fråga sig hur det står till med inskrifterna i tablå 3 (s. 110112), som utgörs av flerradiga inskrifter med osäker läsordning. Vissa av dessa är delvis inkluderade i Åkerströms grupp 1. Undersöker vi de 14 inskrifterna i tablå 3 , finner vi att elva inskrifter har tre rader eller fler i ett och samma inskriftsparti. ${ }^{1} \mathrm{Av}$ dessa elva inskrifter har sex rak läsordning $\mathrm{i}$ de partier som har tre eller fler rader (G 280, Òg N288, DR 110, DR 230, Sm 144 och Òg 136 Rök $^{2}$ ), så de kan uteslutas. Av de resterande fem inskrifter som tillåter byte av läsriktning (alltså, som inte har rak läsordning), byter samtliga fem läsriktning två eller fler gånger. På DR 209, sida A, ändras läsriktningen två gånger, och på sida $\mathrm{B}$ ändras den fyra gånger. DR 4 är svåranalyserad men har enligt Åkerström fyra rader och tre byten av läsriktning. DR 190 har två byten av läsriktning. DR EM85;151B är också den komplicerad, men om man utgår från Åkerströms analys av inskriftens rader, ändras riktningen två gånger. Också DR 192 har tre byten av läsriktning om man utgår från Åkerströms analys av inskriften. Enligt denna analys består emellertid inskriften av fyra rader, vilket inte är korrekt; rad 4 finns egentligen på sida B. Även om man tar bort denna fjärde rad, ändrar dock inskriften riktning två gånger $\mathrm{i}$ de tre raderna på sida $\mathrm{A}$. Det finns alltså säkra bevis på att man kan växla riktning två gånger i en tidig vikingatida inskrift.

Om Åkerström i stället menade ett "hopp" över rad 2 (från rad 3 till rad 1) på Birka-amuletten, finns det även här motexempel. Således börjar t.ex.

\footnotetext{
${ }^{1}$ Jag utesluter DR MLUHM1983-84;131, trots att Åkerström anger att den har fyra rader i ett och samma inskriftsparti. Inskriften är dock fördelad på tre olika sidor: rad 1-2 på sida $\mathrm{A}, \operatorname{rad} 3$ på sida $\mathrm{B}$ och rad 4 på sida $\mathrm{C}$.

${ }^{2}$ På s. 72 anger Åkerström att Ȯg 136 har bustrofedon. I så fall menar hon parti C, rad 26 (se tablå 3, s. 112). Det är den enda raden i hela inskriften som byter riktning enligt bustrofedonprincipen. Jag utesluter även Rökstenen, eftersom inget indikerar att dess rader löper bustrofedon.
} 
inskriften på DR 40 på en mittenrad, varefter man läser den rad som ligger till vänster om mittenraden för att sedan gå vidare till den rad som ligger till höger om mittenraden. Andra exempel på samma företeelse är DR 209 och DR 230. I dessa inskrifter byts visserligen inte läsriktningen, men det görs ett hopp som motsvarar det på Birka-amuletten. Om Åkerström åter menar att ett sådant hopp aldrig får kombineras med ett byte av läsriktningen, kan man betrakta DR 1. På dess sida A löper raderna bustrofedon; läsningen börjar i mittraden, varpå man läser raden till höger om mittraden och därefter den till vänster. Menar hon i stället att det inte finns exempel på någon inskrift som har ett sådant hopp och där inskriftens rader löper bustrofedon och byter riktning exakt två gånger? I så fall, har hon möjligen rätt, men det finns sådana exempel utanför hennes material: upplägget på DR 62 (som inte ingår i Åkerström analys på grund av den relativt sena dateringen till 970-1020-talet) innehåller två hopp över rader samt fyra byten av läsriktning.

Den betydande skillnaden mellan hur jag - och minst ytterligare två runologer - ser på Birka-amulettens läsordning och hur Åkerström förstår inskriftens läsordning, har gjort mig nyfiken på de semiotiska resurser som Åkerström urskilt i sin analys. Tyvärr diskuteras inte frågan om deras inbördes relation i hennes artikel. Kan man tänka sig en inskrift som har tydligt större och mer glest placerade runor i början av den rad som är inskriftens längsta och som är placerad i skriftytans mitt, men där inskriftens lässtart ändå finns i en annan av inskriftspartiets rader? Kan man överhuvudtaget bortse att en viss inskrift har stora runor på en framträdande plats och utan vidare börja läsa någon annanstans? Är det detta som de 27 tidigvikingatida inskrifterna i grupp 1 lär oss att göra?

Åkerströms analys av Birka-amuletten inleds med att hon fastslår att de resurser hon urskilt i sitt arbete med huvudsakligen tidigvikingatida runstenar kan appliceras på lösföremål. Det finns enligt henne inte några "indikationer på att andra resurser förekommer i ristningar på lösföremål jämfört med dem på sten (förutom att objektets orientering i rummet inte är given för lösföremål i samma utsträckning)". Detta är ett problematiskt resonemang, eftersom indikationerna kan saknas som en följd av att läsordningen på vikingatida lösföremål aldrig undersökts systematiskt. Självfallet är det dock ändå inte principiellt omöjligt att jämföra skriftkonventioner i monumentala offentliga inskrifter med konventionerna i privata inskrifter på lösföremål.

I nästa steg föreslår Åkerström att vända Birka-amulettens inskrift så att dess rader kan läsas vertikalt. Hon eliminerar på så sätt den enda skillnad mellan inristade lösföremål och steninskrifter som hon själv just under- 
strukit. Jag finner det svårt att följa Åkerströms argumentation för varför raderna skall placeras vertikalt. Hon skriver: "För att kunna diskutera de resurser som förutsätter att radernas riktning kan fastställas antar jag att resursen läsriktning $i$ rad kan tillskrivas Björköhängets komposition; radernas riktning bestäms alltså genom att hänget vrids så att startraden alltid ligger vertikalt med en läsriktning nedifrån och upp." Här förefaller mycket vara problematiskt. För att man skall kunna vrida hänget utifrån en startrad, måste denna först fastställas. För det andra är det åtminstone för mig långt ifrån självklart varför Åkerström väljer att aktualisera "de resurser som förutsätter att radernas riktning kan fastställas", om det finns så många andra resurser som uttrycker framskjutenhet och som också kan appliceras här, t.ex. runstorlek, runtäthet, radlängd och så vidare. För det tredje motsäger valet av resursen läsriktning $i$ rad Åkerströms egen definition av densamma. Resursen läsriktning $i$ rad definierar hon på följande sätt (s. 64): "resursen innebär just att lässtart i ett vertikalt radupplägg finns i en rad vars läsriktning löper nedifrån och upp.” För att använda resursen, måste man alltså ha ett säkert vertikalt upplägg med läsriktning nedifrån och upp. Detta förutsätter i sin tur ett fixerat läsläge, som bara runstenar kan erbjuda, för hur annars kan man veta vad som är "nere" och vad som är "uppe".

Som vi snart skall se, väljer Åkerström också att i inskriften urskilja resursen radlängd. Resursen radlängd är en komplex benämning, så vitt jag förstår, för den syftar egentligen på två olika resurser. Den ena uttrycker framskjutenhet och behandlar helt enkelt sådant som den längsta (eller kortaste) raden i en inskrift. Jag kommer att kalla denna resurs för radlängd. Den andra resursen, som jag kommer att kalla kantradlängd, är endast möjlig att urskilja i en vertikal komposition och uttrycker läsväg (s. 71, 80). I en sådan vertikal komposition syftar nämligen benämningen (kant)radlängd på den av två kantrader som är längst, oavsett hur långa de andra raderna i inskriften är. I fallet med Birka-amuletten är det just denna kantradlängd som Åkerström urskiljer (s. 92): "Resursen radlängd kan indikera lässtart i en längre kantrad och avslutning i den kortare, vilket här innebär start i rad 1 och avslut i rad 4. Dock erbjuds inte lässtart i rad $1 \mathrm{i}$ dess egenskap av kompositionens längsta rad; rad 2 och 3 är något längre."

Hade Åkerström inte placerat hänget vertikalt, hade hon inte kunnat urskilja denna resurs, och som vi redan sett är den vertikala placeringen problematisk. Det tycks emellertid finnas ännu ett problem med denna resurs. Resursen radlängd används ofta (det finns 12 eller 14 exempel hos Åkerström, s. 66), medan det endast finns exempel på resurs kantradlängd 
i tre inskrifter: DR 29, DR 202 och Ög 136 (sida A). I alla dessa tre fall kombineras emellertid kantradlängd med ytterligare resurser för att skapa ett erbjudande till lässtart. (Jag använder mig här och nedan bara av de resurser som Åkerström i sin artikel själv urskilt och rapporterat för dessa runstenar.) På DR 29 kombineras resursen med radlängd och läsriktning $i$ rad. På DR 202 kombineras den med radlängd och runstorlek. På Ög 136 (A) kombineras den med radlängd, runstorlek och runtäthet. Jag vill därför redan utifrån Åkerströms eget arbete starkt ifrågasätta att resursen kantradlängd skulle kunna tillämpas separat. Rad 1 på Birka-amuletten erbjuder oss inte någon annan resurs som skulle indikera att inskriftens start finns just här.

I detta sammanhang bör även de semiotiska resursernas inbördes relation diskuteras. Nästan inga av de resurser som Åkerström urskilt kan utifrån Åkerströms eget arbete användas separat. Om vi till exempel väljer radlängd, används denna enligt Åkerströms material uteslutande tillsammans med resurserna runstorlek, runtäthet och radläge. Så fort inskriften inleds med en längre rad, kan man hitta antingen större och/ eller glesare placerade runor i början av raden (Ög 136, DR 202, DR 209, DR 230, DR 248, DR MLUHM1983-84;131; två exempel måste jag utesluta ur Åkerströms analys: på DR 30 ser jag inte några mindre runor eller någon kortare rad i inledningen, och på Sm 144 [sida B] ser jag ingen framskjuten längre rad). Även när resursen radlängd betecknar en visuellt kortare rad, kombineras den antingen med visuellt större (Ög 8, DR 250) eller med visuellt mindre runor (Ög N288). Resursen radlängd kombineras även gärna med resursen radläge, vilken innebär att inskriftens längsta rad står på en visuellt framskjuten plats, till exempel överst eller i mitten (U 4, DR 29, DR 40, DR 202, DR 209 [sida C], DR 230, DR 248, DR 250, DR MLUHM1983-84;131). Den enda resursen som enligt min analys av Åkerströms material kan användas ensam är runstorlek (DR 41, DR 110), och detta öppnar upp en helt ny horisont. Det betyder enligt min mening att om en viss inskrift har större runor i början av en rad, som dessutom skjuts fram på något annat sätt i förhållande till andra rader, krävs synnerligen goda argument för att föreslå lässtart någon annanstans. Vi ser exempel på detta fenomen även inuti inskrifter, när t.ex. ett nytt inskriftsparti ska börja. De två horisontella raderna på Ȯg 136 (sida A) kan tas som exempel: den nedre raden är längre medan den övre har större runor, och alla språkliga tolkningar har det gemensamt att lässtarten för dessa rader är i den övre.

Åkerström indelar de semiotiska resurserna i sådana som hon menar resulterar i ett starkt respektive svagt markerat erbjudande. Hon nämner 
att resurserna kan framträda tydligt och otydligt samt att vissa av dem kan manifesteras i frekventa och infrekventa varianter (således är större respektive mindre runor två olika manifestationer av resursen runstorlek). På så sätt kan Åkerström bedöma den samlade styrkan av resursernas erbjudande. Hon menar att det också ibland är svårt att bedöma situationen med erbjudanden (s. 62): "Flera otydliga resurser kan tillsammans resultera i ett starkt markerat erbjudande om läsordning, medan flera motsägelsefulla, men tydliga, resurser kan resultera i flera svagt markerade erbjudanden. ... Flera infrekventa resurser skulle tillsammans kunna ge ett starkt markerat erbjudande om läsordning, medan flera frekventa resurser som pekar i olika riktningar kan resultera i olika svagt markerade erbjudanden." Tyvärr anges inte vilka inskrifter i grupp 1 som har starkt och vilka svagt markerade erbjudanden, vilket hade krävts för att vi skulle kunna jämföra med de tre inskrifter på vilka Åkerström prövar sin modell. Dock anges att större runor är den mest frekventa varianten av resursen runstorlek (s. 69), att en längre rad är den mest frekventa varianten av resursen radlängd (s. 69) samt att glesare runor är den mest frekventa varianten av resursen runtäthet (s. 68). (Jämför också tablå 1 på s. 80 , där den mest frekventa varianten markeras med versaler.) Vi får inte veta vilka resurser som används oftare än andra, men man kan misstänka att resursernas placering i tablå 1 är hierarkisk. Denna placering sammanfaller i alla fall med min egen analys av Åkerströms material, som ger vid handen att runstorlek är det som oftast används, varefter följer radlängd, radläge och runtäthet.

Åkerström säger (s. 62) att "En frekvent resurs antar jag resulterar i ett starkare markerat erbjudande och tvärtom”. På Birka-amuletten har vi tre tydliga resurser i rad 2 i deras mest frekventa varianter (större och glesare runor samt längre rad). Dessa är dessutom de tre mest populära resurserna överhuvudtaget. Här är det också viktigt att erinra sig att resursen runstorlek i sin frekventa variant större runor kan användas självständigt. Enligt min mening har alltså rad 2 på Birka-amuletten ett mycket starkt erbjudande om lässtart, starkare än alla de andra raderna.

Det är nu dags att gå vidare till nästa rad. Radordningen 1-2-3-4, som Åkerström föreslår, baseras på resurserna kantradlängd och närliggande startpunkt för rad (s. 92 f.): "Resursen närliggande startpunkt för rad kan också peka på läsordningen 1-2-3-4 eftersom raderna då löper bustrofedon. Om hänget vrids så att startrad $1 \mathrm{i}$ enlighet med resursen läsriktning $i$ rad löper nedifrån och upp, går läsordningen 1-2-3-4 från raden längst till höger och sedan mot vänster. Denna utformning av resurserna placering av rad och radordning finns i grupp 1 men är mindre 
frekvent jämfört med det omvända (från vänster mot höger).” Som vi ser beror denna resurs återigen på att Birka-amuletten har placerats vertikalt och på att resursen läsriktning $i$ rad tillämpas.

Som en annan möjlig läsordning (men med ett mindre starkt markerat erbjudande) föreslår Åkerström 2-1-3-4. Efter rad 2 väljer hon att läsa rad 1 (där jag väljer rad 3). Återigen baseras detta förslag på att hänget har placerats vertikalt, eftersom Åkerström anger att rad 1 nu är belägen till vänster om rad 2. Om rad 1 är till vänster om rad 2 betyder det att Birkaamuletten har placerats vertikalt, och läsningen i rad 2 löper nerifrån och upp (s. 93): ”Om lässtart finns i mittraden 2 förutsätts en läsväg där ordningen raderna läses i växlar riktning. Istället för den ordning som Imer presenterar - en typ som inte finns representerad i grupp 1 - föreslår jag den variant av resurserna placering av rad och radordning där läsväg först går mot raden till vänster (1) och därefter fortsättning mot höger (3-4), alltså 2-1-3-4".

Att rad 3 uttrycker framskjutenhet på samma sätt som rad 2, diskuteras inte av Åkerström. Inte heller diskuteras möjligheten att placera inskriften horisontellt; i sådant fall skulle rad 2 ligga på ett visuellt framskjutet ställe i den övre delen av hängets skriftyta (dock inte överst), medan rad 3 skulle ligga direkt under. I sin analys av de tidigvikingatida runinskrifter med säker läsordning har Åkerström visserligen få horisontella kompositioner (s. 77), men de som finns följer just denna läsordning: "Eftersom beläggen är få på rader som med säkerhet ligger horisontellt är det emellertid svårt att säga något bestämt om sådana varianter av placering av rad respektive radordning. Det finns emellertid ett säkert exempel, de horisontala raderna i parti A på Ög 136, på att lässtart hittas i översta raden med en läsväg uppifrån och ned."

Sammanfattningsvis måste tyvärr konstateras att Åkerströms kritik av Imers och Snædals läsordning inte håller. Det tycks också finnas brister i analysmodellen, framför allt i hur de semiotiska resurserna analyseras och appliceras.

\section{Nytolkning}

Jag vill försöka att läsa inskriften enligt den läsordning som jag etablerat ovan som den mest tilltalande, dvs. raderna läses nedan i ordningen 2-31-4. Jag ordindelar translittereringen enligt min tolkning och markerar med symbolen ¿de runor som jag vill dubbelläsa:

\section{pat ik uitki nona_as non kuki tun aki saka rak hit pa pik}


Runföljden pat kan tolkas som det demonstrativa pronomenet sá 'detta' i sg. n. ack., pat. Runföljden ik kan läsas som det personliga pronominet $e k$ 'jag' i 1 pers. sg. Runorna uitki vill jag läsa som ett verb motsvarande det fornisländska (vidare: fisl.) verbet vitka i 1 pers. sg. pres. konj. Verbet betyder 'laste, klandre ein for noko' (Norrøn ordbok) eller 'to bewitch' (Cleasby och Vigfusson). Fritzner anger att verbet kan användas som synonym till det fornisländska verbet magna 'styrke, gjøre stærkere; i Prosa kun om at sætte i Besiddelse af overnaturlige Kræfter ved Hjælp af Trolddom.' Hos Fritzner kan vi även finna verbet finn-vitka 'hexe, øve Trolddom paa Finnernes Maade eller ved deres Hjælp'.

Att verbet vitka hade betydelsen 'förtrolla, förhäxa' antyder också den betydelse som verbet fick i sin reflexiva form vitkast'få forstanden tilbake, sansa seg, komme til seg sjølv' (Norrøn ordbok). Betydelsen av verbet vitka antyds också av sådana bildningar som vitki m.'trollmann' och vitt $\mathrm{n}$. 'trollskap, trolldomsmiddel' (Norrøn ordbok).

Inskriften vill jag således inleda på följande sätt: pat ik uitki, Pat ek vitki, 'Må jag förtrolla detta'.

Därefter kommer en svårtolkad runsekvens nona och en liknande sekvens snon i nästa rad. Mina försök att finna ytterligare ett verb i denna runföljd har inte givit några säkra resultat. Verbet motsvarande fisl. nenna 'nenne, ha lyst til, finne seg i, bry seg om', 'bruke, nytte' eller 'fare, reise' (Norrøn ordbok) hade kunnat vara en stark kandidat. Detta verb har också föreslagits av Otto von Friesen, men som jag påpekar ovan bör verbet böjas nenni i 1 pers. sg. pres. ind. eller pres. konj. Det skulle i och för sig vara möjligt ett läsa non som imperativ i 2 pers. sg. Nenn! 'Nyttja! Använd!' eller 'Far!', men det är svårt att hitta en passande fortsättning för runorna a snon som blir kvar.

Jag väljer därför att tolka nona som ett substantiv motsvarande nyisländska nenna f. 'energy' (Cleasby och Vigfusson). Ordet är inte belagt i fornisländska och tas därför inte upp av Fritzner eller i Norrøn ordbok, men dess närvaro kan postuleras med hjälp av sådana ord som nennu-lauss och nenningar-lauss adj. 'sløv, blottet for Lyst til at foretage sig eller udrette noget' och nenning f. 'Foretagsomhed, Virksomhed, Virkelyst' (Fritzner). I Lexicon Poeticum hittar man även ordet nenninn adj. 'dygtig, energisk, ufortrøden'. Ordet finns även belagt i medeltida svenska. Söderwall anger att nänna f. betyder 'mod, raskhet, rådighet'.

Jag dubbelläser a-runan i föregående rad och får på så sätt runföljden as, som kan tolkas som verbet vesa 'vara' i 3 pers. sg. pres. ind., es. Runföljden non kan tolkas som motsvarigheten till fisl. nánn/náinn adj. 'nær' (Fritzner), 'nærliggande, befindende sig i Nærheden' (Lexicon Poeticum). 
Ordet kan i substantiverad form användas som heiti för brynja i fornisländska: náin f. 'den som ligger nära' (Lexicon Poeticum och The Skaldic Project).

Meningen nona s non Nænna es nān 'Kraften är när' eller 'den/det som ligger nära (kapseln/hänget) är styrka/kraft' passar slående föremålets egenskaper: en kapsel som hänger nära bröstet och som torde ha innehållit något stoff som ansågs ha skyddande eller magiska egenskaper.

Runortografiskt innebär det inte något problem att /e/-ljudet i es här skulle återges med a-runan, as, i synnerhet som det föregående ordet slutar på /a/. Formen es istället för er är heller inte något problem, utan snarare en fördel, eftersom formen är äldre. Det är förvisso inte särskilt vanligt att en runa vid dubbelläsning återger två olika fonem, men det finns säkra exempel på denna företeelse. Särskilt frekvent finner vi sådana exempel på Åsmund Kåressons runstenar från 1000-talets mitt. På U 192 finns runföljden pinoftir, som har tolkats penna æftiR; här läser man först o-runan som nasalt /a/ och därefter som /æ/. På U 241 träffar vi på runföljden onklanti, som har tolkats $\bar{a}$ Anglandi: o-runan läses först som nasalt /a/ och sedan som /æ/. På U 824 finner vi följden pinabtir som tolkas penna æftiR; a-runan står först för nasalt /a/ och därefter för /æ/.

Att återge /æ/ och /a/ som nasalerade ljud med o-runan förefaller också oproblematiskt. I nænna och nān står /æ/ och /a/ mellan två nasala konsonanter, vilket stärker förutsättningarna för att beteckna vokalerna med o-runan. Exempel på att /a/ återges med o efter eller före nasal är många, och behöver inte särskilt ges. Exempel på att /e/ eller /æ/ återges med o efter eller före nasal, går också att hitta i danska, norska och svenska vikingatida runinskrifter. Det demonstrativa pronomenet sāsi i ackusativform pennal pænsi 'denne' skrivs således ponsi med o på fler än 20 runstenar från Danmark. ${ }^{3}$ Formerna pono eller pona för penna förekommer både i Norge och på Isle of Man. ${ }^{4}$ Det personliga pronomenet pæiR 'de' i dat. pæim 'dem' skrivs poi på DR 230, adv. længi 'länge' ristas loki på DR 131 m.m. ${ }^{5}$

Också på att /æ/ kan återges med o framför eller efter nasalkonsonanter finns exempel på tidigvikingatida runstenar i Sverige; således ristas t.ex. på Rökstenen (Ỏg 136) ordet drængR m. 'ung man'i dat. sg. drængi som troki (se också Vg 61 trok). På Sparlösastenen (Vg 119) ristas ordet natt f. 'natt' i pl. nom. nættr som notu.

${ }^{3}$ DR 1, 63, 68, 96, 97, 108, 114, 118, 120, 121 (ponnsi), 123, 124, 130, 131, 144, 145, 154, 155, 209, 230, 239, 259, 339, DR EM85;312 och DR EM85;523B.

${ }^{4}$ N 208, N 247, IM MM131, IM MM132, IM MM135 och IM MM136.

${ }^{5}$ På DR 192 och DR 333 ristas verbet standa 'stå' i 3 pers. sg. pres. stændr som stotr. På DR 3 ristas konjunktion æn som ion, på DR 217 ristas det relativa pronomenet sæm som. 
Runföljden kuki är svårt att tolka på något annat sätt än som ett substantiv motsvarande fisl. kyngi f. 'kunnskap i trolldom, trollskapp' (Norrøn ordbok) eller 'Dygtighed til at øve Trolddom' (Fritzner). Ordet förekommer även som fjölkyngi f. 'Trolddom, Hexeri' (Fritzner), där fjöl fungerar som ett slags förstärkning 'mycket' (Fritzner skriver att fjöl adv. betyder 'meget' och förekommer 'kun som første Del af sammensatte Ord'). Ordet har även avledningar, t.ex. fjölkyngiliga adj. 'paa Troldmænds vis'. Ordet ingår även i två sammansättningar hos Fritzner: fö̈lkyngisbók f. 'Trolddomsbog, Bog som indeholder Anvisning til Trolddom' och fjölkyngisfolk $\mathrm{n}$. 'Mennesker som give sig af med Troldom, øve Troldomskunst'. Att den nasala konsonanten /n/ saknas framför klusilen /g/ i kuki stämmer väl med vikingatida runortografi.

Vidare blir det svårt att tolka tun på något annat sätt än ett verb motsvarande fisl. týna 'fordærve, tilintetgjøre', 'miste, tabe' (Fritzner) eller 'gløyme' (Norrøn ordbok, se betydelse 3 för ordet) i imperativform týn. Verbet kräver objekt $\mathrm{i}$ dativ, men detta är inte något problem för tolkningen, eftersom ordet kyngi är oförändrat i dativ. Runföljden aki kan förstås som adverbet $e k k i$ 'icke, inte, ej'.

Meningen kuki tun âki vill jag alltså tolka som Kyngi tȳn ekki!'Glöm/ Tappa/Förstör inte trolldomen (eller: den magiska kunskapen)!'

Runföljden saka kan tolkas som ett verb motsvarande fisl. saka 'skade en, tilføie ham noget ondt' (Fritzner). Detta verb kan också betyda 'sake, klage, skulde [beskulde], laste ein for noko' (Norrøn ordbok). Verbet står här i 1 pers. sg. pres. ind. och meningen måste därför betraktas som subjektslös. Sådana subjektslösa satser finns det flera exempel på just i tidigvikingatida inskrifter. Det mest kända exemplet är de satser på Rökstenen som börjar med Sagum ... 'Vi säger ...' (Holmberg et al. 2020, 20). Exempel på att en bindruna används på gränsen mellan två ord finns också; det mest kända är bindrunan ưf på satsgräns på Sigtunablecket: fliupunưfuntinis Flȳ pū nū ! Fundinn es ... (Pereswetoff-Morath 2019a, 106).

Runföljden rak kan tolkas som substantivet rek n. i ack. 'Saksøkning, Forfølging' eller 'hvad som driver, tilskynder, bevæger en til noget, Bevæggrund', 'Foretagende, Bestræbelse hvormed man søger at faa udrettet noget, fremmet en Sag' (Fritzner). Ordet rek rymmer dessutom samma betydelser som $r q k$ (och $r ø k$ ) n. pl. 'utvikling; opphav, årsak, grunn; vitnesbyrd, teikn; hendingar, forhold; lagnad, ende' (Norrøn ordbok). På så sätt får vi här två ord, verbet saka och substantivet rek, som bägge kan höra till lagspråk.

Runföljden hit kan tolkas som pronomenet hinn 'den' i n. ack., hitt. Runföljden pa kan förstås som ett verb motsvarande fisl. piggja 'få, ta 
imot' (Norrøn ordbok) eller 'komme i Besiddelse af noget som begjæres, gives', 'optage noget paa en eller anden Maade' (Fritzner). Verbet böjs $p \bar{a}$ 'fick, tog i besittning' i 3 pers. sg. pret. ind. De resterande runorna pik kan tolkas som det personliga pronomenet $p \bar{u}$ 'du' i ack., pik'dig'.

Meningen saka rak hit po pik Saka rek hitt pā pik 'Jag skadar den förföljelse/de omständigheter som tog dig i besittning/fångade dig' passar de två föregående meningarna väl. Hela inskriften tolkar jag således som:

pat ek vitki: nænna es nān. Kyngi tȳn ekki. Saka rek hitt pā pik.

'Må jag förtrolla detta: kraften är nära (eller: det som ligger nära [hänget] är kraften). Förstör inte (eller: tappa inte, glöm inte) den magiska kunskapen. Jag skadar den förföljelse/de omständigheter (som) tog dig i besittning.'

Vi får tyvärr aldrig veta vad som förföljde denna kvinna, men det förefaller i alla fall helt möjligt att hon vände sig till en runkunnig magiker för att försvara sig mot det. Att hon sedan bar amuletten nära bröstet på sitt finaste halsband är också rimligt med tanke på formelns stränga förbud att inte tappa eller förstöra den magiska kraft som amuletten rymde. Runmästaren kan därför nu i efterhand betraktas som framgångsrik. Hon eller han lyckades med sitt trolleri: föremålet har inte tappats bort eller förstörts och tack vare det har budskapet gått fram till våra dagar. Magikern, vem det nu än var, försökte för övrigt inte att dölja sitt budskap med hjälp av krypterade runor. Tvärtom, trots föremålets obefintliga storlek, ristades runorna så tydligt och klart som det bara gick på en så liten yta. Och föremålets kraft har återupplivat kvinnan för oss, en kvinna som annars fick en för hennes tid, ställning och plats helt typisk begravning. Vad förföljde och oroade henne? Var också det något typiskt? En arvstvist? Eller var det något förfärligare och mer ovanligt? Det är nu hur som helst över, och kanske Birka-amuletten kan ha spelat sin roll i det.

\section{Författarens tack}

Arbetet med denna artikel finansierades av Gun Widmarks fond. Jag är tacksam mot Kungliga Gustav Adolfs Akademien för svensk folkkultur som genom detta bidrag har möjliggjort det föreliggande arbetet. Jag vill även tacka Gunnar Andersson, förste antikvarie vid Statens historiska museum, för att ha möjliggjort mina studiebesök till museet. 


\section{English summary}

\section{The runes on the Birka amulet revisited}

In this paper I have offered a new reading and interpretation of the Birka amulet. My reading differs from two previous ones, by Arthur Nordén (1937) and by Lisbeth Imer and Thorgunn Snædal (in Imer 2007). I am unable to discern any older $M$-runes in the inscription, nor do I see any $f$-runes and I do not believe that the inscription contains short-twig runes beyond the single exception of $\mathbf{n}$. I identify three new bind-runes, none of which I consider the result of a mistake. My transliteration is, in roworder 1-2-3-4:

\section{sakârakhitp̣a | patikuitkinona | snonkukitunậi | pik}

$\begin{array}{llllllll}1 & 5 & 10 & 15 & 20 & 25 & 30 & 35\end{array}$

My reading order is however a different one. I suggest first reading row 2 followed by row 3 . These two rows share several similarities in their visual representation and row 2 is certainly marked as the beginning not only by means of larger runes and wider spaces between these but also by the length of the row and the number of runes per row. After these two rows I suggest proceeding to row 1 and subsequently row 4 . I discuss my reading order in detail and compare my results with those of Hanna Åkerström (2020), which I believe to be flawed by a number of logical inconsistencies. My reading is as follows (the symbol $\smile$ is used to show runes read twice):

\section{pat ik uitki nona_as non kuki tun aki saka rak hit pa pik}

My normalisation to runic Scandinavian and translation are:

Pat ek vitki: nænna es nān. Kyngi tȳn ekki! Saka rek hitt pā pik.

'May I bewitch this: the power is close (or: the thing that is close [i.e. the amulet] is power). Do not destroy (or: do not lose, do not forget) the magic knowledge! I harm the pursuit/the circumstances that got you.'

All the words employed in my interpretation are represented in Old Scandinavian and the interpretation does not violate the orthographical norms of Viking Age runic writing as far as I can see, nor does the interpretation contravene the morphological and syntactical rules of runic Scandinavian. I do not suggest that mine is the only possible interpretation as the nature of runic writing is such that it is possible to divide the runic sequences of the inscription differently. My interpretation makes perfect sense, however, for a small object worn close to the body on a daily basis. 


\section{Förkortningar och bibliografi}

Arbman, Holger. 1939. Birka: Sveriges äldsta handelsstad. Stockholm.

—. 1940a. Birka: Untersuchungen und Studien, vol. 1: Die Gräber: Text. Stockholm.

—. 1940b. Birka: Untersuchungen und Studien, vol. 1: Die Gräber: Tafeln. Stockholm.

ATA = Antikvarisk-topografiska arkivet, Riksantikvarieämbetet. Stockholm.

Cleasby och Vigfusson = Cleasby, Richard, och Gudbrand Vigfusson. An IcelandicEnglish Dictionary. Oxford, 1957.

Danmarks runeindskrifter. Av Lis Jacobsen och Erik Moltke. 3 vol.: Text; Atlas; Registre. København, 1941-1942.

$\mathrm{DR}+\mathrm{nr}=$ inskrift publicerad i Danmarks runeindskrifter.

DR EM85; + sidonr = runinskrift publicerad i Erik Moltke, Runes and Their Origin, Denmark and Elsewhere (Copenhagen, 1985).

DR MLUHM1983-84;131 = inskrift publicerad i Lars Larsson och Evert Salberger, "A Rune-Inscribed Detail of a Comb from L:a Köpinge, Scania”, Meddelanden från Lunds universitets historiska museum 1983-1984: 128-137.

Duczko, Wladyslaw. 1980. "Vikingatida smycken i Mora-skatten: Den icke-monetära delen av en nyupptäckt silverskatt från Dalarna." Tor 18: 311-357.

—. 1985. Birka: Untersuchungen und Studien, vol. 5: The Filigree and Granulation Work of the Viking Period: An Analysis of the Material from Björkö. Stockholm.

Fritzner = Johan Fritzner. Ordbog over Det gamle norske Sprog. 3 vol. Kristiania, 1886-1896. Vol. 4: Tillegg og rettelser. Av Finn Hødnebø. Oslo, 1972.

Fuglesang, Signe Horn. 1989. "Viking and Medieval Amulets in Scandinavia." Fornvännen 84: 15-27.

$\mathrm{G}+\mathrm{nr}=$ inskrift publicerad i Gotlands runinskrifter, dvs. SRI, 11-12. För nummer över G 222 se Helmer Gustavson och Thorgunn Snædal, manus till Gotlands runinskrifter, del 3. http://www.raa.se/kulturarvet/arkeologi-fornlamningaroch-fynd/runstenar/digitala-sveriges-runinskrifter/gotlands-runinskrifter-3/

Gräslund, Anne-Sofie. 1980. The Burial Customs: A Study of the Graves on Björkö. Vol. 4 av Birka: Untersuchungen und Studien. Stockholm.

Holmberg, Per, Bo Gräslund, Olof Sundqvist och Henrik Williams. 2020. ”The Rök Runestone and the End of the World." Futhark 9-10 (2018-2019): 7-38.

Jesch, Judith. 1991. Women in the Viking Age. Woodbridge: Boydell.

IM MM = inskrift från Isle of Man, Manx Museum, publicerad i Michael Barnes, The Runic Inscriptions of the Isle of Man, Runrön, 22 (London, 2019).

Imer, Lisbeth M. 2007. "Runer og runeindskrifter: Kronologi, kontekst og funktion i Skandinaviens jernalder og vikingetid", vol.: "Katalog”. Doktorsavhandling, Det Humanistiske Fakultet, Københavns Universitet.

Lexicon Poeticum = Lexicon Poeticum Antiquæ Linguæ Septentrionalis/Ordbog over det norsk-islandske skjaldesprog. Av Sveinbjörn Egilsson; rev. Finnur Jónsson för det Kongelige Nordiske Oldskriftselskab. 2 utg. Copenhagen, 1931.

MacLeod, Mindy. 2002. Bind-Runes: An Investigation of Ligatures in Runic Epigraphy. Runrön, 15. Uppsala. 
$\mathrm{N}+\mathrm{nr}$ = inskrift från Norge, publicerad i Norges innskrifter med de yngre runer, av Magnus Olsen et al., 6 vol. hittills (Oslo, 1941-).

N KJ40 = inskrift från Norge (Setrekammen) publicerad i Wolfgang Krause och Herbert Jankuhn, Die Runeninschriften im älteren Futhark, vol. 1: Text, vol. 2: Tafeln, Abhandlungen der Akademie der Wissenschaften in Göttingen, Philologisch-Historische Klasse, 3 ser., 65 (Göttingen, 1966).

Nordén, Arthur. 1933. 'Trollrunor mot blodförgiftning." Stockholmstidningen, 26 februari.

— . 1937. "Magiska runinskrifter." Arkiv för nordisk filologi 53: 147-189.

—. 1940. "Litteratur och kritik: Tysk runforskning under de sista åren." Fornvännen 35: 318-332.

Norrøn ordbok = Leiv Heggstad, Finn Hødnebø och Erik Simensen. Norrøn ordbok. 4 utg. av Gamalnorsk ordbok av Marius Hægstad och Alf Torp. Oslo, 1997.

Pereswetoff-Morath, Sofia. 2019a. Viking-Age Runic Plates: Readings and Interpretations. Runrön, 21; Acta academiae regiae Gustavi Adolphi, 155. Uppsala.

—. 2019b. "Vikingatida runbleck: Läsningar och tolkningar." Korpuskatalog till doktorsavhandling, Institutionen för nordiska språk, Uppsala universitet. http://urn.kb.se/resolve?urn=urn:nbn:se:uu:diva-383584

Samnordisk runtextdatabas. Institutionen för nordiska språk, Uppsala universitet. http://www.nordiska.uu.se/forskn/samnord.htm

The Skaldic Project = Skaldic Poetry of the Scandinavian Middle Ages. http:// skaldic.abdn.ac.uk/db.php

$\mathrm{Sm}+\mathrm{nr}=$ inskrift publicerad i Smålands runinskrifter, dvs. SRI, 4.

$S R I=$ Sveriges runinskrifter. Olika författare; publicerade av Kungl. Vitterhets Historie och Antikvitets Akademien. 14 vol. hittills. Stockholm, 1900-.

SRI, 2 = Östergötlands runinskrifter, av Erik Brate (1911).

SRI, 4 = Smålands runinskrifter, av Ragnar Kinander (1935-1961).

SRI, 5 = Västergötlands runinskrifter, av Hugo Jungner och Elisabeth Svärdström (1940-1970).

SRI, 6-9 = Upplands runinskrifter, av Elias Wessén och Sven B. F. Jansson (1940-1958).

SRI, 11-12 = Gotlands runinskrifter, av Sven B. F. Jansson, Elias Wessén och Elisabeth Svärdström (1962-1978).

Söderwall $=$ Knut Fredrik Söderwall. Ordbok öfver svenska medeltidsspråket. 2 vol. Lund, 1884-1918.

$\mathrm{U}+\mathrm{nr}=$ inskrift publicerad i Upplands runinskrifter, dvs. SRI, 6-9.

U ANF1937;172 = inskrift på en bennål hittad i Svarta jorden på Birka 1924 och publicerad i Nordén 1937, 171-176.

$\mathrm{Vg}+\mathrm{nr}=$ inskrift publicerad i Västergötlands runinskrifter, dvs. SRI, 5.

Åkerström, Hanna. 2020. "Läsordning i tidigvikingatida runristningar." Futhark 9-10 (2018-2019): 39-134. Upptryck i hennes Visuella textkonventioner $i$ den tidiga vikingatidens runristningar. Doktorsavhandling, Institutionen för nordiska språk, Uppsala universitet. Uppsala, 2020.

Ög $+\mathrm{nr}=$ inskrift publicerad i Östergötlands runinskrifter, dvs. SRI, 2. 